\title{
XVII A. ANTROSIOS PUSĖS KARAI IR MŪŠIAI LIETUVOS DIDŽIOSIOS KUNIGAIKŠTYSTĖS HUSARŲ TEKSTUOSE
}

\author{
Vidmantas Airini
}

Klaipedos universiteto Baltijos regiono istorijos ir archeologijos institutas

Anotacija. Straipsnyje aptariami XVII a. antrosios pusés Lietuvos Didžiosios Kunigaikštystès kariuomenès husaru tekstai, jais remiantis analizuojamos sunkiosios kavalerijos kariu patirtys XVII a. karuose su Rusija, Švedija ir Osmanu imperija bei karybos istorijai svarbūs reiškiniai. Remiantis karuose tiesiogiai dalyvavusiu kavaleristu atsiminimais ir korespondencija, aptariamas husarų pasiruošimas ir dalyvavimas karo veiksmuose, ju vaidmuo mūšiuose, taip pat kariu požiūris vadovybę, santykiai su savo dalinio ir kitu daliniu kariais, disciplinos klausimai bei karinès tradicijos. Sunkiuju kavaleristų tekstai atskleidžia ir svarbius Lietuvos kariuomenes dalyvavimo XVII a. karuose aspektus. Tai gyvas savo kariuomenes ir priešu kariuomeniu veiksmu aprašymas, karo veiksmu teatrais tapusiu kraštu ir ju vietoviu apibūdinimas.

Pagridiniai žodžiai: husarai, husarų véliavos, kavalerija, sunkioji kavalerija, Lietuvos kariuomenès tautinio autoramento sunkioji kavalerija, Lietuvos Didžiosios Kunigaikštystès kariuomenè (LDK kariuomenè), XVII a. karai, XVII a. antrosios pusés karai, karybos istorija, taktika, atsiminimai, kariu tekstai, Lietuvos Didžiosios Kunigaikštystès kariuomenès husarų tekstai.

\section{IVADAS}

XVII a. Lietuvos Didžiosios Kunigaikštystès (toliau - LDK) kariuomenei buvo svaiginančių pergalių ir skaudžių pralaimejjimų, iki tol nepatirtų rimčiausių išbandymų epocha. Kariuomenès finansavimo sunkumai, konfliktai valdančiojo elito gretose, neretai pasitaikantys kariuomenès vadovybès nesutarimai su valdovo dvaru, dažnai nuo kunigaikštystès ribų labai nutolę karo veiksmų teatrai arba karas priešų kariuomenių 
okupuotame savo krašte buvo ta tikrové, realios sąlygos, kuriomis kovėsi Lietuvos kariuomenè. XVII a. LDK kariuomenès ir jos formuočių istorija iki šiol lieka mažai ištirta. Tiriant karus ir juose dalyvavusias kariuomenes, itin didelę reikšmę turi dalyvių korespondencija, dienoraščiai ir atsiminimai.

Daugiausia tyrèjų ir plačiosios visuomenès dèmesio sulaukè kariuomenès ir jos dalinių vadovybès reliacijos, tačiau siekiant suvokti karinių kampanijų, mūšių ir operacijų eigą bei pasiruošimą, reikalingi pačių karių ir jų tiesioginių vadovų parašyti tekstai. Tokie rašytiniai šaltiniai yra negausūs, mažiau žinomi, sulaukę nepakankamai dèmesio, tačiau susipažinimas su jais padeda geriau suvokti karo tikrovę, jo ịvykių eigą, ịvertinti jame dalyvaujančių kariuomenių pasirengimą, aprūpinimą, jos junginių, dalinių, padalinių ir pavienių asmenų veiksmus ir aplinkybes. Šie tekstai atskleidžia reiškinius ir ịvykius, dẻl skirtingų priežasčių nutylètus kariuomenès vadų ir aukštų pareigūnų oficialiuose raštuose ir asmeniniuose užrašuose. Kalbant apie Lietuvos kariuomenę, galima išskirti jos smogiamosios dalies - husarų vèliavų ${ }^{1}$ - karių rašytinị palikimą.

Aptariama šaltinių grupe yra sulaukusi Lietuvos, Lenkijos ir Rusijos istorikų demesio. Lietuvoje tai XVII a. vidurio problemoms skirti šviesaus atminimo LDK istorijos tyrèjo Antano Tylos darbai. Istorikas rèmèsi dviejų būsimų Lietuvos kariuomenės husarų atsiminimais tirdamas $1658 \mathrm{~m}$. Verkių mūšio aplinkybes, karinius ir politinius padarinius ${ }^{2}$, taip pat LDK iždo vaidmenį užtikrinant valstybès gynybą ir išlikimą 16481667 m. karų laikotarpiu³.

1 Vèliava, kuopa (lenk. choragiew, rota, rus. xopyzвb, poma) - Lenkijos karalystès ir LDK kariuomenių organizacinis vienetas, išlikęs iki XVIII a. Vèliavomis buvo ịprasta vadinti husarų, kazokų, šarvininkų ir petihorų, lengvụjų raitelių ir tautinius pėstininkų organizacinius vienetus. Taip kartais buvo įvardijami ir reitarų, vokiškujų pèstininkų ir dragūnų organizaciniai vienetai (eskadronai ir kuopos). XVII a. husarų vèliavą sudare rotmistras, poručnikas, vèliavininkas, draugai ir jų palydos (paaiškinimus žiūrèkite toliau, pirmą kartą terminą paminejjus tekste). Kaip ir kitų kavalerijos rūšių, husarų vèliavos buvo įvairaus dydžio, nors daugumą jų sudaré nuo 100 iki 150 žirgų (kavaleristų etatų). Gausiausios buvo etmonų vèliavos, kurias turejjo sudaryti apie 200 žirgų. Dalis etatų (visų pirma rotmistrų, poručnikų palydose) buvo formalūs, todèl tikrasis vèliavoje tarnaujančių karių skaičius mažesnis, nei nurodyta rejestruose.

2 A. Tyla, Verkių mūšis (1658 10 21), Lituanistica, 2007, t. 69, Nr. 1, p. 25-35.

3 A. Tyla, Lietuvos Didžiosios Kunigaikštystés iždas per Dvidešimtmetį karą (1648-1667), Vilnius, 2010, p. 144, 189, 190, 191-194, 211, 224, 241, 251, 258, 264, 266-269, 352. 
Kai kurių husarų tekstais, rengdamas šiai kavalerijos rūšiai Lietuvos kariuomeneje skirtą publikaciją ${ }^{4}$, rèmèsi ir šio straipsnio autorius. XVII a. antrosios pusés karų ir Lietuvos kariuomenès husarų vėliavų dalyvavimo juose tema remiantis šiais šaltiniais atskleista tik iš dalies. Daug demesio husarų tekstams skyrè ir jais savo tyrimuose remėsi Lenkijos istorikai. Šioje kaimynineje šalyje buvo parengtos aptariamų šaltinių publikacijos. Husarų rašytinio palikimo potencialas atskleistas jaunosios kartos istoriko ir žymaus husarų istorijos specialisto Radoslavo Sikoros (Radosław Sikora) darbuose ${ }^{5}$. Autoriaus publikacijos skirtos Abiejų Tautų Respublikos (toliau - ATR) kariuomenių husarų vèliavų istorijai, tad, nagrinėdamas jas kaip karinị vienetą, jis neturejo tikslo gilintis $\mathfrak{i}$ Lietuvos kariuomenès husarų ypatumus. Karių atsiminimai - svarbi šaltinių grupe tiriant karų ir pavienių karinių kampanijų eigą. Tai atskleidè $1660 \mathrm{~m}$. karinei kampanijai Lietuvoje skirta Kšištofo Kosažeckio (Krzysztof Kossarzecki) monografija ${ }^{6}$. Savo darbe istorikas rèmèsi gausiais naratyviniais šaltiniais, kuriems priklauso ir mus dominantys karo veiksmuose dalyvavusių LDK kavaleristų tekstai. Užbėgant ị priekį, galima prasitarti, kad Lietuvos sunkiosios kavalerijos karių rašytinis palikimas bus įtrauktas ị naują Lietuvos husarams XVII a. vidurio karuose skirtą publikaciją, kurią rengia kitas jaunosios kartos Lenkijos istorikas, Varšuvos universiteto Istorijos instituto darbuotojas Konradas Bobiatynskis (Konrad Bobiatyński) ${ }^{7}$. Rusijos kariuomenès péstininkų istorijos ir XVII a. vidurio ATR ir Rusijos karo kontekste vieno lietuvių husaro užrašais rėmėsi ir Rusijos istorikas Aleksandras Malovas (Александр В. Малов) ${ }^{8}$.

Šio straipsnio tikslas - ištirti XVII a. antrosios pusès Lietuvos kariuomenès husarų tekstus, jais remiantis išanalizuoti sunkiosios kavalerijos karių patirtis XVII a. karuose ir karybos istorijai svarbius reiškinius.

4 V. Airini, Pro Deo et Patria. Lietuvos Didžiosios Kunigaikštystès husarai 1500-1673. Abieju Tautu Respublikos husaru ginkluotè Vytauto Didžiojo karo muziejaus rinkiniuose, Kaunas, 2013.

5 R. Sikora, Niezwykłe bitwy i szarże husarii, Warszawa, 2012; R. Sikora, Fenomen husarii, Warszawa, 2013.

6 K. Kossarzecki, Kampania roku 1660 na Litwie, Zabrze, 2005.

7 LDK husarams XVII a. vidurio kariuose su Rusija ir kazokais skirtą K. Bobiatynskio straipsnį planuojama publikuoti ATR husarų istorijai skirtame straipsnių rinkinyje.

8 А. В. Малов, Московские выборные полки солдатского строя в начальный период своей истории. 1656-1671 г2., Москва, 2006, с. 457-459. 
Keli LDK husarų vèliavų kariai aprašè 1655-1691 m. karų ịvykius. Jie dalyvavo karuose su Švedija, Osmanų imperija ir Rusija. Susitelksime i karo veiksmus, kuriuose juos aprašę kariai dalyvavo tiesiogiai. Ypatingą dèmesị skirsime žinioms apie pačių husarų pasiruošimą ir dalyvavimą karuose, jų vaidmeniui mūšiuose, karinėse operacijose, karinėms tradicijoms ir kasdienybei. Svarbus karių požiūris ị tiesioginę ir aukščiausią vadovybę, santykių su savo ir kitų dalinių kariais, disciplinos klausimai. Aptarsime ir kai kuriuos kitus sunkiụjų kavaleristų tekstuose atskleidžiamus Lietuvos kariuomenès dalyvavimo XVII a. karuose aspektus: karo veiksmų teatrais tapusių kraštų, juose esančių vietovių, savo kariuomenės ir priešu kariuomenių ir jų veiksmų aprašymą. Kai kurie kavaleristai išsiskyre itin ilga karine karjera, kurią pradejjo ne husarų, o kitose kavalerijos vèliavose. Pastarasis karių užrašuose atsispindintis jų tarnybos ir aktyvaus dalyvavimo karo veiksmuose laikotarpis svarbus ne tik LDK kariuomenès ir jos kavalerijos istorijai pažinti, bet ir husarų vèliavas sudarančių karių pasirengimo, kovinès patirties klausimams aptarti.

Verta atkreipti demesi $i$ tai, kad mums žinomos XVII a. pirmosios pusès husarų reliacijos yra skirtos tam tikriems ịvykiams, vienai arba kitai karinei kampanijai. Jos padeda pažinti mus dominančią husarų dalinių istoriją, yra svarbios nustatant kai kuriuos jos faktus. Tačiau šiu tekstų kalba pernelyg lakoniška, aprašomas laikotarpis per trumpas, tad pateikiamos žinios - fragmentiškos, nepadedančios atskleisti LDK kariuomenès husarų vèliavų dalyvavimo XVII a. karuose visumos vaizdo. Visiškai kitokias galimybes Lietuvos kariuomenès ir jos sunkiosios kavalerijos istorijai tirti suteikia XVII a. antrojoje puseje kariuomenejje tarnavusių kavaleristų atsiminimai. Būtent jie atskleidžia svarbius kariuomenès organizacijos, ginkluotès, taktikos ypatumus, kai kurias karių buities detales ir tradicijas.

\section{APIE AUTORIUS IR JŲ TEKSTUS}

Prieš pereidami prie XVII a. antrosios pusès Lietuvos kariuomenės husarų tekstų apžvelkime jų pirmtakų palikimą. Kai kuriuos XVII a. pirmosios pusès reliacijose aprašomus ịvykius ir reiškinius galima palyginti su vèlesnių laikų situacija. Daugiau demesio skirsime trims amžiaus antrosios pusés kariams ir jų tekstams. 
Mus dominančioms XVII a. pirmosios pusès reliacijoms būdingas eiliuotas tekstas. 1620-1621 m. karą su Osmanų imperija nušvietė Lietuvos kariuomenès husarų rotmistras ${ }^{9}$, Naugarduko vèliavininkas ir kaštelionas Jonas Rudamina (Jan Rudomina). Jo dienoraštis skirtas $1621 \mathrm{~m}$. Lenkijos karalystès ir LDK pajègų žygiui prieš Osmanų imperiją nušviesti. Chotyno kampanijos įvykiams aprašyti jis pasirinko eiliuotą tekstą, o po juo pasirašė „neturtingo kareivio“ Frydricho Važachtigo (Fridrych Warzachtig) vardu ${ }^{10}$. Reliacijos originalo kalba - lenkų. Ji paskelbta 1640 m., saugoma Jogailos bibliotekoje Krokuvoje. Nagrinèdamas ATR husaru dalyvavimo Chotyno mūšyje klausimus, šiuo šaltiniu rèmėsi R. Sikora ${ }^{11}$.

Eiliuoto teksto forma parašyta ir kito Lietuvos kariuomenès kario Jono Kunovskio (Jan Kunowski) ${ }^{12}$ reliacija, pavadinta „1621 m. Livonijos ekspedicija“. Jos autorius tarnavo draugu ${ }^{13}$ Aleksandro Korvino Gosevskio (Aleksander Korwin Gosiewski) husarų vèliavoje. Ypatingai vertingą

9 Rotmistras (lenk. rotmistrz, rus. pomмuсmp, vok. Rittmeister) - Lenkijos ir LDK kariuomenèse samdytos kavalerijos arba pėstininkų vėliavos ar kuopos vadas. XVI a. pèstininkų kuopų vadai pradèti vadinti kapitonais, o rotmistrais - tik tautinès péstijos (vadinamųjų lenkiškųjų, vengriškųjų ir rinktinių) vèliavų bei kavalerijos vadai. XVII-XVIII a. tautinės kavalerijos (husarų, kazokų, šarvininkų ir petihorų) vèliavų rotmistrais paprastai tapdavo ne profesionalūs karininkai, o dignitoriai, žymūs ir pasiturintys valstybès veikèjai, o vietoj jų vèliavoms tiesiogiai vadovaudavo poručnikai ir vietininkai.

10 Diariusz prawdziwy expediciej Korony Polskiej y Wielkiego Xięstwa litewsk. Przeciw Osmanowi Cesarzowi Tureckiemu w roku 1621 Pod Chocimem w Wołoszech fortunnie odprawioney, 1640.

11 R. Sikora, Niezwykłe bitwy i szarże husarii, s. 54-56, 62, 64.

12 Reliacija paskelbta Ekspedycyja inflantska 1621 roku, Białystok, 2007.

13 Draugas (lenk. towarzysz, ukr. mовариu) - vėliavos samdomas karys, paprastai stojantis ị tarnybą su savo palyda, sudaryta iš kelių (XVII a. dažniausiai 2-3) raitelių. XVI a. draugai pakeitè riterius ir perèmè jų karines funkcijas. Tai buvo Lenkijos ir LDK kavalerijos vẻliavų branduolys. Draugai turèjo apsirūpinti patys ir aprūpinti žirgais, ginklais, ekipuote ir kitais žygiui skirtais dalykais savo palydas. Palydos raiteliai (pocztowe, pachołki) buvo eiliniai kariai, kurie lydėdavo draugus tiek karinèse kampanijose, tiek kautynèse, kai išvien su jais turejdavo kautis. XVII a. viduryje husarų draugas savo palydoje dažniausiai turèdavo du, rečiau - tris arba vieną eilinį. Šiuo laikotarpiu ịprastas draugų ir eilinių santykis buvo 1:2, todèl pirmieji sudarydavo apie trečdalị visos vèliavos karių. Tokị husarų vèliavose tarnavusių draugų palydų, o kartu ir vèliavų dydị lèmé seimeliai. Jiems siekiant, kad draugų palydoje būtų ne daugiau kaip trys žirgai, ịprastą husarų palydą XVII a. antrojoje puseje sudarydavo draugas ir du palydos raiteliai. J. Wimmer, Wojsko polskie w drugiej połowie XVII w., Warszawa, 1965, s. 266. 
šio teksto dali sudaro $1621 \mathrm{~m}$. lapkričio $28 \mathrm{~d}$. kautynių prie Kropimoizos ežero ${ }^{14}$ (netoli Kuoknesès) aprašymas. Šioje vietoje švedų kavalerijos grupę atakavo LDK kariuomenès daliniai. Husaro J. Kunovskio reliacija paskelbta $2007 \mathrm{~m}$. Balstogèje. Jos originalo kalba - lenkų. Šioje publikacijoje paskelbtas J. Kunovskio plunksnai priklausantis tekstas kartu su jam vadovavusio A. K. Gosevskio rašytais laiškais yra pagrindiniai šaltiniai mažai žinomoms Kropimoizos kautynèms nušviesti.

XVII a. antrosios pusès karus Lietuvos kariuomenès tautinio autoramento ${ }^{15}$ sunkiosios kavalerijos kariai aprašè ị savo pasakojimą įtraukdami žymiai platesni laikotarpị. Dienoraščio forma parašyti atsiminimai suteikia galimybę ịvertinti husaru pasiruošimo karui aplinkybes, materialinio aprūpinimo aspektus, atsekti karinès karjeros vingius. Dauguma LDK kariuomenės kavaleristų tekstų nèra tokie stilistiškai turtingi ir detalūs kaip, pavyzdžiui, jų amžininkų, ATR tarnavusių pastabių ir smalsių prancūzų. Karūnai ${ }^{16}$ tarnavusio artilerijos ir inžinerijos specialisto Giljomo Levasero de Boplano (Guillaume Levasseur de Beauplan) ${ }^{17}$ ir kare lenkų bei lietuvių pusẻje dalyvavusio 17 metų jaunuolio Antuano Gramono

14 Kropimoizos ežeras yra dabartinès Latvijos teritorijoje ir žinomas Lobės vardu (Lobes ezers).

15 Autoramentas (lenk. autorament) - vienodais pagrindais organizuota kariuomenès dalis. Lenkijos ir LDK kariuomenèse autoramentai buvo įforminti apie $1632 \mathrm{~m}$., vykstant Vladislovo Vazos karinems reformoms. Padidinus ir reorganizavus vakarietiškąją kariuomenès dalį - reitarų, dragūnų ir vokiškųjų pėstininkų dalinius - buvo sudarytas svetimšalių autoramentas. Tautinį autoramentą sudarè husarų, kazokų (vèliau šarvininkų), petihorų, lengvosios kavalerijos vèliavos ir lenkiškosios organizacijos pèstininkai. Svetimšalių autoramentas buvo organizuotas iš regimentų (pulkų) arba atskirai veikusių kuopų. Tautinio autoramento raitija ir pèstininkai sudare vèliavas. Pastarųjų karinėse kampanijose sudaryti pulkai buvo ne nuolatiniai organizaciniai vienetai, o laikini junginiai. Svetimšalių autoramento regimentų vadovybę sudarė pulkininkai, pulkininkai leitenantai ir majorai, kuopu - kapitonai, leitenantai ir eiliniams vadovaujantys puskarininkiai. Tautinio autoramento vèliavų vadovybę sudarè rotmistrai, poručnikai ir vietininkai, jiems buvo pavaldūs draugai ir jų palydos. Autoramentai išliko iki 1775-1776 m. karinių reformų, pakeitusių Lenkijos karalystės ir LDK kariuomenes.

16 Karūna (lenk. Korona) - istoriniuose šaltiniuose ir istoriografijoje Lenkijos karalystei ivvardyti dažnai vartojamas terminas.

17 Г. Левассеръ де Бопланъ, Описаніе Украины отъ пределовъ Московіи до границъ Трансильваніи, составленное Гильомомъ Левассеръ де Бопланъ, В. Г. Ляскоронскій, Гильомъ Левассерь де Бопланъ и его историко-геограбическіе труды относительно Южной Россіи. I. Описаніе Украины. II. Карты Украины, Кіевъ, 1901. 
(Antoine Gramont $)^{18}$ tekstai, be kita ko, atskleidžia reikšmingus XVII a. karybos aspektus, kurie lietuvių ir lenkų kariams atrode savaime suprantami, todèl neverti aprašymo. Tai pastebima ir LDK kariuomenès husaru tekstuose. Lietuvių kariai mažai dėmesio skyrè ginkluotès, aprangos, buities detalių apibūdinimui, nemėgino palyginti savo ir priešų kovos būdų. Kavaleristai stengèsi glaustai fiksuoti svarbiausius ịvykius ir jų aplinkybes, tačiau jų perduodamų žinių visuma leidžia kur kas daugiau sužinoti tiek apie XVII a. karus, tiek apie juose dalyvavusią Lietuvos kariuomenę.

Ivykius raštu fiksuoti linkusių karių tekstuose randame žinių apie 1654-1667 m. Abiejų Tautų Respublikos ir Rusijos karo pradžią. 1655 m. žiemą ịvykusią Lietuvos kariuomenès ir pagalbinių Lenkijos kariuomenès dalinių ofenzyvą, mėginant susigrąžinti praejusiais metais prarastas teritorijas, nušviečia tiek Lietuvos kariuomenès vadovybès, tiek jų dalinius sudariusių karių rašytinis palikimas. Pirmajai šio palikimo grupei priklauso didžiojo etmono Jonušo Radvilos ir jo pusbrolio Lietuvos arklidininko Boguslavo Radvilos korespondencija ir paskutiniojo parašyta autobiografija $^{19}$. Šiuos XVII a. karų tyrimams, be abejo, vertingus šaltinius papildo LDK kariuomenės gretose kovojusių karių tekstai. Vienas tokių yra žiemos kampanijoje dalyvavusio Lietuvos kariuomenès kavaleristo reliacija, kurioje vaizdingai aprašyti $1655 \mathrm{~m}$. vasario $16 \mathrm{~d}$. lemtingo Mogiliavo šturmo ivvykiai. Šiame puolime dalyvavo Lietuvos lauko etmono Vincento Aleksandro Korvino Gosevskio (Wincenty Aleksander Korwin Gosiewski) husarų vèliava, kurioje tuo metu tarnavo Vladislovo Vazos gerai žinomo gydytojo Motiejaus Vorbeko-Letovo (Maciej Vorbek-Lettow) sūnus Kristupas (Krzysztof). Vasario $26 \mathrm{~d}$. tèvui rašytame laiške jis smulkiai apibūdino savo vèliavos dalyvavimą šturme. Lenkų kalba parašytas Kristupo Vorbeko-Letovo laiškas ịtrauktas ị jo tėvo Motiejaus atsiminimų publikaciją ${ }^{20}$.

18 А. Грамонь, Изъ исторіи московскаго похода Яна Казимира (1663-1664 г. г.). Под ред. И. И. Лаппо, Юрьевь, 1929; A. Gramont, Iš Jono Kazimiero žygio ị Maskvą istorijos (1663-1664), Lietuvos kariuomenè svetimšalių akimis XVI-XVII a., Vilnius, 2009, p. 144-170.

19 Korespondencja wojskowa hetmana Janusza Radziwiłła w latach 1646-1655, Część 1. Diariusz kancelaryjny 1649-1653, Warszawa, 2019; B. Radziwiłł, Autobiografia, Warszawa, 1979, s. 129.

${ }^{20}$ Laiškas įtrauktas it M. Vorbeko-Letovo atsiminimų publikaciją. Vorbek-Lettow M. Skarbnica pamięci, Wrocław-Warszawa-Kraków, 1968, s. 218-221. 
Vienas iš dviejų šiam straipsniui daugiausiai žinių suteikusių karių yra atsiminimų autorius Jonas Vladislovas Počobutas Odlanickis (Jan Władysław Poczobut Odlanicki). Jo gimine kildinama iš Ukmergès pavieto. Atsiminimų autorius gyveno 1640-1703 m., tarnavo kariuomeneje, buvo aktyvus politinio LDK gyvenimo dalyvis, tapo Ašmenos stalininku. Karo tarnybą J. V. Počobutas Odlanickis pradèjo $1658 \mathrm{~m}$. rugpjūtí, būdamas dar visiškai jaunas - 18 metų. Tarnaudamas pašauktinių bajorų gretose jis dalyvavo kovose su Rusija, vèliau - su švedų pajegomis Kurše. 1659 m., sulaukęs 19-os, atsiminimų autorius įstojo i̇ poručniko ${ }^{21}$ Adomo Motiejaus Sakavičiaus (Adam Maciej Sakowicz) vadovaujamą Lietuvos lauko etmono Vincento Korvino Gosevskio husarų veliavą, kurioje keleriais metais anksčiau tarnavo ir Kristupas Vorbekas-Letovas ${ }^{22}$. Ši vèliava priklausè V. K. Gosevskio vadovaujamam kairiajam Lietuvos kariuomenès sparnui ${ }^{23}$. Per trejus pirmuosius tarnybos Lietuvos kariuomenejje metus J. V. Počobutas Odlanickas patyrè ir aprašè sudètingą 1658-1660 m. situaciją, kai LDK kariuomenei teko kariauti dviem frontais. Šiaureje buvo kovojama su Respublikos vasalo Kuršo kunigaikščio valdas užèmusiais ir išvaduotą Žemaitiją puldinejjančiais Švedijos kariuomenès feldmaršalo Roberto Douglaso (Robert Douglas) daliniais ir tuo pat metu priešintis caro pajègoms, kurios vis dar kontroliavo didelę 1654-1655 m. užimtos LDK teritorijos dali. $1660 \mathrm{~m}$. Počobuto Odlanickio vèliava dalyvavo priešų užimto Vilniaus apgultyje, vèliau - karo veiksmuose prieš rusų kariuomenę rytinėse LDK žemėse. Žuvus V. K. Gosevskiui, jo husarų vėliavų rotmistru tapo Mykolas Kazimieras Pacas (Michał Kazimierz Pac).

${ }^{21}$ Poručnikas (lenk. porucznik, rus. поручuк) - Lenkijos ir LDK kariuomenėse samdytos kavalerijos ir péstininkų vèliavos arba kuopos vado pavaduotojas, atitinkantis leitenantą. XVII a. rotmistrais vis dažniau tapdavo aukštas valstybines pareigas eję civiliai asmenys, todèl poručnikai ir vietininkai tapo tiesiogine tautinio autoramento vèliavų vadovybe.

${ }^{22}$ Nežinia, ar pastarasis galejjo dalinyje tarnauti po dramatiškų 1655-ųjų ir vẻlesnių metų ìvykių.

${ }^{23}$ LDK kariuomenę sudarę dešinysis ir kairysis sparnai šaltiniuose ir mokslinėje literatūroje taip pat vadinami ir divizijomis. Dešiniojo ir kairiojo sparno divizijomis ịprasta vadinti didžiojo etmono ir lauko etmono bei kai kuriais atvejais skiriamo regimentoriaus vadovaujamus junginius. Nuo $1656 \mathrm{~m}$. Lietuvos didžiojo etmono Povilo Sapiegos vadovaujamas dešinysis LDK kariuomenès sparnas buvo vadinamas Sapiegos divizija (dywizja Sapieżyńska), o Žemaitijoje suformuotas ir sukomplektuotas Lietuvos lauko etmono V. K. Gosevskio vadovaujamas kairysis sparnas - Žemaitijos divizija (dywizja żmudzka). 
Atsiminimus parašęs husaras dalyvavo Lenkijos ir Lietuvos karaliaus Jono Kazimiero vadovaujamame 1663-1664 m. žygyje ị Rusiją. Jis išsamiai apibūdino šị nepasisekusị bendrų Lenkijos karalystės ir LDK pajėgụ bandymą suduoti smūgị caro valstybei.

Apžvelgiant J. V. Počobuto Odlanickio atsiminimų likimą, verta paminèti kelis pagrindinius šio šaltinio publikavimo istorijos faktus. $1877 \mathrm{~m}$. Varšuvoje buvo išleista pirmoji Počobuto Odlanickio atsiminimų publikacija $^{24}$. Rankraščio (autografo) nuorašas buvo parengtas Leono Potockio (Leon Potocki), o Juzefas Ignacas Kraševskis (Józef Ignacy Kraszewski) palygino šị nuorašą su rankraščiu ir papilde ji paaiškinimais. Praejjus daugiau kaip šimtmečiui, jau 1987 m. vèl Varšuvoje pasirodė antroji publikacija, kurią komentarais papilde žymus Lenkijos istorikas, LDK tyrëjas Andžejus Rachuba (Andrzej Rachuba) ${ }^{25}$. Apskritai Počobuto Odlanickio atsiminimai apima 1640-1684 m. laikotarpi. Tekstas parašytas dienoraščio forma, tačiau vietomis įrašų apie konkrečias dienas neturintys laiko tarpai galejo būti užpildyti vèliau užrašytais atsiminimais. Vertindamas šaltinyje dominuojančių užrašų pobūdị, Aloyzas Saikovskis (Alojzy Sajkowski) lietuvių kario palikimą siūlè vadinti „karo tarnybos dienoraščiu“ (dyaryusz służby wojennej), taip pripažindamas, kad tai - dienoraštis-atsiminimai, t. y. šaltinis, turintis tiek dienoraščio, tiek atsiminimų elemen$\operatorname{tuc}^{26}$. Idomiausia ir vertingiausia husaro atsiminimų dalis skirta tarnybai Lietuvos kariuomeneje, tačiau jie buvo tęsiami iki $1684 \mathrm{~m}$. Tuo metu karo veiksmai LDK teritorijoje buvo pasibaigę prieš 17 metų, tad kario atsiminimai peržengia „karo tarnybos dienoraščio“ ribas. Naratyvinių šaltinių tyrejjas A. Saikovskis mane, kad kavaleristo atsiminimai galejo atsirasti dviem etapais: pirmoji dalis, kuri apima kovų su Rusija ir Švedija aprašymą, parengta apie $1680 \mathrm{~m}$., remiantis kiek pakrikais užrašais ir atsiminimais, antroji - nuo 1680 iki 1684 m. - buvo tęsiama kaip tikras dienoraštis $^{27}$. J. V. Počobutas Odlanickis buvo daugumos atsiminimuose minimų ịvykių dalyvis arba liudininkas. Pagrindinę atsiminimų dalị sudaro LDK kariuomenès dalyvavimo karuose su rusais ir švedais aprašymai, tačiau atsiminimų autorius rašè ir apie privačius savo giminès bei viešuosius

24 Pamiętnik Jana Władysława Poczobuta Odlanickiego (1640-1684), Warszawa, 1877.

25 J. Wł. Poczobut Odlanicki, Pamiętnik 1640-1684, oprac. A. Rachuba, Warszawa, 1987.

26 Ten pat, s. 12-13.

27 Ten pat, s. 93. 
reikalus. Sprendžiant iš lenkų kalba parašyto teksto, kuriame neretai pasitaiko rašybos klaidų, J. V. Počobutas Odlanickis neturẻjo gero išsilavinimo, tačiau, turint omenyje šio žmogaus karinę patirtị, jojimo ir fechtavimo ịgūdžius, jị be dvejoniu galima vadinti tikru kariu, tikru husaru. Karo veiksmus savo atsiminimuose jis apraše gana išsamiai. XIX a. kavaleristo atsiminimus su kitais šaltiniais palyginęs Edvardas Menda (Edward Menda) pateikè labai teigiamą vertinimą. Tyrèjas teigè, kad atsiminimuose trūksta faktų, kurie prieštarautų kituose šaltiniuose esančioms žinioms, jie gana objektyvūs, užpildantys kituose atsiminimuose esančias spragas, o neretai ir vienintelis informacijos šaltinis ${ }^{28}$.

Susipažinkime su paskutiniuoju autoriumi ir jo rašytiniu palikimu. Tai XVII a. mažai žinomos Lietuvos bajorų giminès atstovas Aleksandras Dionisas Skorobohatas (Aleksander Dionizy Skorobohaty). Būsimas kavaleristas gimè $1639 \mathrm{~m}$. Jo tèvas Teodoras Jonas Skorobohatas (Teodor Jan Skorobohaty) buvo Trakų pavieto bajorijos atstovas. Skorobohatai nepriklause iškilių, garsių LDK bajorų gretoms, mat $1590 \mathrm{~m}$. vis dar nebuvo visas teises turinčios pavieto bajorijos dalis. Vis dèlto $1621 \mathrm{~m}$. kariuomenès surašymas rodo giminès padèties pokyčius. Skorobohatai jau buvo tapę visateisiais bajorais ${ }^{29}$. Kiek žinoma, A. D. Skorobohatas turejjo keturis brolius ir tris arba keturias seseris. I kariuomenę jis įstojo $1654 \mathrm{~m}$. gruodị, sulaukęs vos $15-$ os $^{30}$.

A. D. Skorobohato karinè karjera buvo labai ilga. Prieš tapdamas husaru, atsiminimų autorius daug metų tarnavo kitose kavalerijos vèliavose. I Lietuvos kariuomenès husarų vèliavą kavaleristas stojo dar labai jaunas, tačiau jau patyręs ir gerai pasirengęs.

Kaip ir J. V. Počobutas Odlanickis, A. D. Skorobohatas karo tarnybą pradèjo šalia savo vyresniojo brolio, kuris ịstojo ị kariuomenę bent trejais metais anksčiau. Aleksandro vyresnysis brolis Benedikatas Kazimieras

\footnotetext{
28 Ten pat, s. 14.

$291621 \mathrm{~m}$. spalio $9 \mathrm{~d}$. visuotinio bajorų šaukimo išvakarèse sudarytame Trakų bajorų sąraše Jurgis ir Dovydas Skorobohatai paminèti kaip Trakų paviete gyvenantys visateisiai bajorai. A. D. Skorobohaty, Diariusz, oprac. T. Wasilewski, Warszawa, 2004, s. 11-12.

30 A. D. Skorobohaty, Diariusz, oprac. T. Wasilewski, s. 16, 26; R. Sikora, Fenomen husarii, s. 194-195.
} 
tuo metu jau buvo patyręs karys ${ }^{31}$. Labiausiai tikètina, kad Aleksandrui D. Skorobohatui įstojus ị kariuomenę, abu broliai tarnavo LDK kariuomenès kairiajame sparne, arba kairiojo sparno divizijoje. Tuo metu divizijai vadovavo Lietuvos lauko etmonas ir didysis iždininkas V. K. Gosevskis abiejų karių vyresniojo brolio ir Lietuvos iždo pareigūno Andriaus Kazimiero Skorobohato vadovas ir globejjas ${ }^{32}$. Dienoraščio autorius iš karto buvo įtrauktas į XVII a. karų verpetą. Kartu su broliu Benediktu jaunasis Aleksandras Skorobohatas dalyvavo LDK teritorijoje vykusiose $1655 \mathrm{~m}$. kovose su rusų kariuomene, $1656 \mathrm{~m}$. karo veiksmuose prieš švedus ir jų sajungininkus Lenkijos karalystès ir Prūsijos kunigaikštystės teritorijoje. Kovèsi su švedais ir 1657 m., kai per Lietuvos teritoriją šiaurẻn nužygiavusi lauko etmono divizija puolè švedų pajègas Livonijoje. Tais pačiais metais abu broliai Skorobohatai iš V. K Gosevskio divizijos perèjo ị Lietuvos lauko raštininko Aleksandro Hilario Polubinskio (Aleksander Hilary Połubiński) ir Oršos vèliavininko, pulkininko Samuelio Kmičico (Samuel Kmicic) vadovaujamą Lietuvos kariuomenès dešinijji sparną. Jo sudetyje abu kariai dalyvavo persekiojant ir įveikiant Švedijos sąjungininko Transilvanijos kunigaikščio Jurgio II Rakočio (György II Rákóczi) vadovaujamą kariuomenę. Tuo metu Aleksandras Skorobohatas tarnavo Oršos pakamario Kristupo Stetkevičiaus (Krzysztof Stetkiewicz) kazokų vèliavoje ${ }^{33}$. Karūnos

31 Anot dominikonų kunigo, žymaus pamokslininko Mykolo Voinilovičiaus (Michał Woyniłowicz) sudarytos ir $1682 \mathrm{~m}$. Vilniuje išleistos panegirikos, jaunesniajam broliui stojant karo tarnybon, Benediktas Kazimieras Skorobohatas jau buvo kovęsis bent keliuose dideliuose, tarp jų - $1651 \mathrm{~m}$. Baltosios Cerkvès (Біла Церква; dab. Ukrainoje, Kijevo srityje) ir $1654 \mathrm{~m}$. Šepelevičių (Шапялевічbl; dab. Baltarusija, Mogiliavo sritis), mūšiuose. A. D. Skorobohaty, Diariusz, oprac. T. Wasilewski, s. 22, 26; R. Sikora, Fenomen husarii, s. 195.

32 A. D. Skorobohaty, Diariusz, oprac. T. Wasilewski, s. 26-27; R. Sikora, Fenomen husarii, s. 195.

33 Kazokų vèliavos, kazokų raitija (lenk. choragwie kozackie, jazda kozacka) - Lenkijos ir Lietuvos kariuomenèse lengvoji ir vidutinè kavalerija, priskirta tautiniam autoramentui. Nuo XVII a. vidurio sukilimo Ukrainoje ši kavalerija pradèjo vis dažniau nešioti žiedinius (grandinius) šarvus. Tokius šarvus turinčios vèliavos pradètos vadinti šarvininkais, šarvininkų raitija, šarvininkų vèliavomis (lenk. pancerni, jazda pancerna, choragwie pancerne). Lietuvos kariuomenejje jų atitikmuo buvo petihorai. Kazokų vèliavų kariai buvo ginkluoti kardais, lankais, ragotinėmis, šautuvais ir pistoletais, dèveddavo žieduočius, misiures (rytietiškus šalmus, susidedančius iš plokščios viršugalvị saugančios dalies (varpo) ir prie jos prikabintos ant pečių krintančios žiedinès dalies), kai kuriais atvejais turèdavo kalkanus - apskritus išgaubtus rytietiškus skydus. A. D. Skorobohaty, Diariusz, oprac. T. Wasilewski, s. 27; R. Sikora, Fenomen husarii, s. 195. 
ir Lietuvos kariuomenes minètuose karo veiksmuose lydejo permaininga sèkmè. Sunkias kovas liudija ir A. D. Skorobohato pavyzdys. $1657 \mathrm{~m}$. liepą buvo pašautas dviem kulkomis ir brolio Benedikto nugabentas i Lvovą. Pagijęs būsimas husaras dalyvavo kovose su Rusijos kariuomene 1658 m., o 1659-1660 m. - švedų užimtų Kuršo pilių apsiaustyse ir Povilo Sapiegos bei Stefano Čarneckio (Stefan Czarniecki) jungtinių pajègų žygyje prieš rusų vaivados Ivano Chovanskio vadovaujamus dalinius. Vèliau paskirtas savo vèliavos deputatu ${ }^{34}$ proviantui Mogiliavo ekonomijoje surinkti. $1660 \mathrm{~m}$. lapkritị atsiminimų autorius paliko K. Stetkevičiaus kazokų vèliavą ir papildè lauko etmono V. K. Gosevskio šarvininkų vèliavos gretas. Tuo metu rusų nelaisveje buvusio lauko etmono vèliavai vadovavo Kauno stalininkas, poručnikas Jonas Aleksandras Ignatavičius Lubianskis (Jan Aleksander Ihnatowicz Łubiański) ir draugu tarnavo žymus atsiminimų autorius Steponas Pranciškus Medekša (Stefan Franciszek Medeksza) ${ }^{35}$.

Tarnybai šarvininkų vèliavoje reikejo apsirūpinti pačiam ir aprūpinti palydą ${ }^{36}$ šarvais, taip pat gerai pasirengti tiesioginiams susidūrimams su priešu ir artimai kovai, kurioje kautis kartais tekdavo trumpesnemis ietimis (lenk. $d z i d y$ ), kuriomis buvo ginkluoti kazokų (ir šarvininkų) vèliavų kariai ${ }^{37}$. A. D. Skorobohato perëjimas iš Povilo Sapiegos divizijos i

34 Deputatas (lenk. deputat) - tautinio autoramento vèliavos administravimo, finansavimo klausimus padedantis spręsti pareigūnas, išrenkamas iš dalinyje tarnaujančių karių vèliavos susirinkime.

35 A. D. Skorobohaty, Diariusz, oprac. T. Wasilewski, s. 28-29; R. Sikora, Fenomen husarii, s. 195-198.

36 Palyda (lenk. poczet) - mažiausias Lenkijos karalystės ir LDK kavalerijos organizacinis vienetas, kurị sudarydavo draugas ir jo išruošti raiteliai. Tokie organizaciniai vienetai sudarydavo vèliavas. Palydos dydị nustatydavo rotmistras arba kariuomenès organizavimą reguliuojantys valdžios potvarkiai. Savo asmenines palydas taip pat turejjo rotmistras, poručnikas ir véliavininkas. XVI-XVIII a. karybos istorijos kontekste poczet kartais reiškia ir vien minètus asmenis lydinčius karius.

37 ATR karinių pertvarkymų projektų autorius, Lvovo kaštelionas ir Podolès vaivada Andžèjus Maksimilijonas Fredro (Andrzej Maksymilian Fredro, apie 1620-1679) kazokų kavalerijai, kuriai galime priskirti ir šarvininkų vèliavas, rekomendavo 5-5,5 alkūnès (apie 3-3,3 m) ragotines - lengvus ir patogius ginklus, jo supratimu, tinkamus kovoti su reitarais, pésčiaisiais kazokais ir totoriais (lengvąja kavalerija). Fredro A. M. Nowe uważenia porządku wojennego względem artykułów dawnych wojskowych, sejmem niekiedy $\mathrm{r}$. pańs. 1609 ztwierdzonych, O porządku wojennym i o pospolitem ruszeniu małem Andrzeja Maksymiliana Fredry. Wyimek z Zwierzyńca Jednorożców, wydanego przez Franciszka Glinkę 1670 r. we Lwowie, oprac. Kazimierz Józef Turowski, Sanok, 1856, s. 39. 
Mykolo Kazimiero Paco diviziją ir jo brolio Andriaus Kazimiero glaudesnio bendradarbiavimo su Pacais pradžia nebuvo atsitiktinis sutapimas. Lietuvos kariuomeneje prasidejo krizè. Dèl neišmokamų algų kariams trūko būtiniausių dalykų tarnybai tęsti. Tarnaudamas ịtampos ir vidinių prieštaravimų draskomoje, tačiau toliau besikaunančioje LDK kariuomenèje, atsiminimų autorius dalyvavo vėlesniuose karo veiksmuose prieš Rusiją rytinėse LDK žemėse ir $1664 \mathrm{~m}$. pradžioje ịvykusiame Karūnos bei Lietuvos dalinių žygyje ị Rusijos gilumą. A. D. Skorobohatas buvo autoritetingas. Būtent jam patikèjo laikinai vadovauti šarvininkų vèliavai iš jos išvykus J. A. Ignatavičiui ${ }^{38}$. Po pergale prieš Maskvą pasibaigusio 1664 m. mūšio prie Vitebsko atsiminimų autoriaus karinejje karjeroje ịvyko didelis pokytis.

1665 m. gegužès mènesị, būdamas 26 metų, jis paliko šarvininkus ir buvo pasamdytas tarnauti Lietuvos didžiojo etmono P. Sapiegos husarų vèliavoje, o po jos išformavimo, mirus etmonui, $1666 \mathrm{~m}$. įstojo i M. K. Paco husarų vèliavą. Tai buvo prestižinis LDK kariuomenès dalinys, kadangi didžiojo etmono buožè valdovo Jono Kazimiero buvo pažadèta Pacui ${ }^{39}$.

A. D. Skorobohatas vedè Konstanciją iš Volskių giminės. Tai buvo naudinga santuoka, mat uošvis Jeronimas Volskis (Hieronim Wolski) buvo pasiturintis žemvaldys ir jo kolega, taip pat tarnavęs husarų vèliavo$\mathrm{je}^{40}$. Beveik nekyla abejonių, kad atsiminimų autorius turejo gerai mokèti kovos trumpesne kazokų (šarvininkų) ietimi veiksmus, kurie jam padejo ivvaldyti ir ilgąą husarų ieti. Tarnaudamas elitiniame sunkiosios kavalerijos dalinyje jis kovèsi garsiame 1673 m. Chotyno mūšyje, dalyvavo vèlesniuose karo veiksmuose prieš Osmanų imperiją. A. D. Skorobohatas buvo Jono Sobieskio karūnavimo dalyvis. 1678 m., mirus pirmajai žmonai, husaras vedė antrą kartą ir padidino savo turtus.

Po M. K. Paco mirties 1683 m. vadovavimą husarų vèliavai, kurioje tarnavo atsiminimų autorius, perèmè pats valdovas Jonas Sobieskis. Tęsdamas tarnybą šioje vèliavoje kavaleristas dalyvavo Lietuvos kariuomenès žygyje prie Vienos, kai atvykti pavėlavę lietuviai nedalyvavo pagrin-

38 A. D. Skorobohaty, Diariusz, oprac. T. Wasilewski, s. 30-32; R. Sikora, Fenomen husarii, s. 198-200.

39 A. D. Skorobohaty, Diariusz, oprac. T. Wasilewski, s. 32-33.

40 Ten pat, s. 33-34. 
diniame mūšyje. Husaras dalyvavo ir vèlesnèse šios kampanijos kovose. Tačiau liga ir sužeidimai privertẻ karị nutraukti tarnybą. $1684 \mathrm{~m}$. pradžioje sergantis ir nuo kontūzijų kenčiantis husaras paliko savo palydą kariuomenejje ir grižo namo vienas. Palikdamas husarų vèliavą jis buvo 45-erių. 11 metų kazokų (taip pat šarvininkų) ir 19 metų husarų vèliavose tarnavęs karys pasveiko, tačiau ị kariuomenę nebegrịžo. 1684-1691 m. kariuomeneje jis toliau išlaike savo palydą, tačiau pats joje nedalyvavo ${ }^{41}$. Dèl ilgos kario karjeros šio kavaleristo dienoraštis apima labai platų karų su Rusija, Švedija ir Osmanų imperija laikotarpi. Lietuvos kariuomenès husaras ir atsiminimų autorius mire $1699 \mathrm{~m}$.

A. D. Skorobohato atsiminimai taip pat parašyti dienoraščio forma. Vadinamasis „Dienoraštis“ (Diariusz) išliko originaliu pavidalu. Rašyti savo atsiminimus kavaleristas pradèjo 1683 arba $1688 \mathrm{~m}$. lenkų kalba. Naudodamasis ịvairiais užrašais, jis suteikè savo atsiminimams dienoraščio pavidalą. Palyginti su J. V. Počobuto Odlanickio tekstu, Skorobohato atsiminimai itin lakoniški. Tik kai kurie įvykiai aprašyti išsamiau. Kai kuriuose praejus daug metų po ịvykių parašytuose atsiminimuose yra klaidų (daugiausia - datavimo), tačiau didelè dalis jų labai vertingi, juose užfiksuoti karų įvykiai neaprašyti arba aprašyti labai skurdžiai kituose šaltiniuose. Vèlesnių Jono Sobieskio valdymo laikotarpio i̇vykių aprašymai gerokai tikslesni nei Jono Kazimiero valdymo laikų ${ }^{42}$. Iš pradžiu A. D. Skorobohato „Dienoraščio“ originalus tekstas buvo jo palikuonių nuosavybè, vèliau keliavo iš vieno savininko kitam. Galiausiai pateko ị Vilniaus viešąą biblioteką, ir čia su juo susipažinti galejai jau 1903 m. Šiuo metu jis saugomas Lietuvos mokslų akademijos Vrublevskių bibliotekoje. Pirmoji šaltinio publikacija pasirodè $2000 \mathrm{~m}$. originalo (lenkų) kalba $^{43}$. Kaip ir J. V. Počobuto Odlanickio atsiminimai, A. D. Skorobohato palikimas turi labai didelę vertę.

${ }^{41} 1691 \mathrm{~m}$. A. D. Skorobohatas prarado iš žygio grižtančią palydą ir jos daugiau nebeatkūrè. R. Sikora, Fenomen husarii, s. 200-204.

42 A. D. Skorobohaty, Diariusz, oprac. T. Wasilewski, s. 39-41.

43 Ten pat, s. 37-39. 


\section{TARNYBOS HUSARŲ VĖLIAVOSE PRADŽIA IR PASIRENGIMAS KARUI}

Kavalerijos dalinių pasirengimas karinei kampanijai yra ịdomi, tačiau mažai nagrinèta tema. Vèliavų ir jas sudarančių palydų organizavimą, apsirūpinimą žirgais, ginkluote, apranga, ekipuote ir visa likusia karui skirta manta pasirinkti naratyviniai šaltiniai atskleidžia fragmentiškai. Juose kur kas daugiau demesio skiriama karo veiksmų eigai, taip pat svarbiausiems karinių kampanijų ịvykiams. Rengimasis vykti ị karą nebuvo vieną karinę kampaniją ar mūši apibūdinančių reliacijų autoriams svarbi tema. Karo tarnybos pradžią ir apsirūpinimą jai reikalingomis priemonemis atsiminimuose trumpai apibūdino jų autoriai Lietuvos kariuomenès sunkieji kavaleristai.

Husarų vèliavų draugais dažniausiai tapdavo dviejų kategorijų žmonès: jaunesnieji sūnūs, kurie gaudavo ekipuotę ir išvykdavo iš tèvų namų ieškoti savo gyvenimo kelio, taip pat mažai žinomų neturtingų bajorų giminių atstovai ${ }^{44}$. Smulkios ar vidutinés bajorų giminès atstovai ir jaunesnieji sūnūs buvo ir atsiminimus palikę husarai. Jonas Vladislovas Počobutas Odlanickis buvo trečiasis, Aleksandras Dionisas Skorobohatas - ketvirtas sūnus šeimoje. Pastarasis tarnavo kaip ir kiti du broliai du jaunesni tos pačios šeimos sūnūs.

Atsiminimuose Počobutas Odlanickis prasitarè, kad, mirus tèvui, mažai laiko praleidęs mokyklose ir mažai mokęsis, $1658 \mathrm{~m}$. vyresniųjų brolių buvo išsiųstas karo tarnybon Ukmergès pavieto pašauktinių bajorų gretose. Pirmasis būsimo husaro dalinys buvo pašauktinių bajorų pajègoms priklausanti Slanimo pakamario Mikalojaus Šemetos kazokų veliava. Joje jis igijo pirmają kovinę patirtị, vykstant nesèkmingoms lietuvių kovoms su Rusijos kariuomene prie Kauno. Atitarnavęs pašauktinių gretose, jis grižo pas šeimą. Tada, kai Lietuva tuo pat metu kovojo su Rusija ir Švedija, o žinios apie karo veiksmus ateidavo iš visų pusių, kare pabuvęs jaunuolis negalëjo ilgai ištverti namie ir buvo pasiryžęs veikti ${ }^{45}$. Praleidęs su šeima kelis mènesius, jis vèl prisijungè prie kariuomenès. Atsiminimuose

\footnotetext{
${ }^{44}$ H. Wisner, Wojsko litewskie I połowy XVII wieku, cz. III, Studia i materiały do historii wojskowości, Tom XXI, Wrocław-Warszawa-Kraków-Gdańsk, 1978, s. 96.

45 R. Sikora, Fenomen husarii, s. 178.
} 
karys paminejjo, kad 1659 m. pirko iš savo vyresniojo brolio Stanislovo trijų husarų žirgų palydą su visa ekipuote ir ketvirtú, atsarginiu, žirgu. Už draugo palydą nurodè broliui sumokèjęs 1600 auksinų (złotych szesnaście set) ir jau netrukus, prieš savo motinos valią, ỉstojo ị poručniko Adomo Motiejaus Sakavičiaus vadovaujamą ,jo malonybès pono didžiojo iždininko ir LDK lauko etmono [V. K. Gosevskio] husarų vèliavą “46. Taip pradèjęs pasakojimą apie tarnybą husarų gretose, atsiminimų autorius ịvardijo stojant $\mathfrak{i}$ elitinị Lietuvos sunkiosios kavalerijos dalinị būtinas investicijas. Jis tapo antruoju tautinio autoramento sunkiojoje kavalerijoje tarnavusiu Počobutų Odlanickių šeimos sūnumi, mat brolis Stanislovas tarnavo vienoje LDK kariuomenès husarų vèliavų 1657-1659 m. Husarų gretas J. V. Počobutas Odlanickis papildè jau paragavęs kario duonos, turẻdamas maždaug vienų metų kovinę patirtị.

Dar daugiau patirties stojant $\mathfrak{i}$ husarų vèliavą turejo Aleksandras D. Skorobohatas, dalyvavęs kovose su Švedijos, Transilvanijos ir Rusijos kariuomenèmis. Karinę karjerą jis pradèjo 15 metų, būdamas dar jaunesnis už J. V. Počobutą Odlanickị. Prieš stodamas ị kariuomenę, jis taip pat neilgai, apie 5 metus, mokèsi. Atsiminimuose A. D. Skorobohatas nurodè pradèjęs mokytis namie $1645 \mathrm{~m}$., būdamas maždaug šešerių. $1648 \mathrm{~m}$. išsiųstas mokytis ị Vilnių, bet $1650 \mathrm{~m}$. dèl užkrečiamosios ligos pavojaus turejęs grịžti namo ${ }^{47}$. Nuo $1654 \mathrm{~m}$. tarnaudamas kariuomenèje, kazokų ir šarvininkų kavalerijoje, jis kovèsi atviro lauko mūšiuose ir dalyvavo daugelio pilių ir įtvirtintų miestų apgultyse ir šturmuose, $1658 \mathrm{~m}$. gruodị puolant rusų užimtą Minską (W Mińsku Moskwę szturmem dostawszy wycięliśmy) arba $1659 \mathrm{~m}$. rugsèji prie Mūšos pavijus ir sumušus švedus (Dogoniliśmy Szwedów nad rzeką Musza i znieśliśmy) ${ }^{48}$. Kavalerijoje karo metu igyti igūdžiai ir patirtis leido atsiminimų autoriui greitai prisijungti prie husarų. Atsiminimuose jis nurodè, kad, $1665 \mathrm{~m}$. gegužès $10 \mathrm{~d}$. palikęs šarvininkų vèliavą, to paties ménesio $20 \mathrm{~d}$. jis stojo ị husarų vèliavos gretas. Apsirūpinti nauja, husarų vèliavoje tarnauti tinkama palyda jam galejjo padèti vyresnis brolis ir globejjas Andrius Kazimieras ${ }^{49}$. Ankstesnès palydos vežimus, žirgus, ekipuotę ir proviantą jis prarado griždamas

\footnotetext{
46 J. Wł. Poczobut Odlanicki, Pamiętnik 1640-1684, oprac. A. Rachuba, s. 126, 128.

47 A. D. Skorobohaty, Diariusz, oprac. T. Wasilewski, s. 61-62.

48 Ten pat, s. 71, 74-75.

49 R. Sikora, Fenomen husarii, s. 200.
} 
iš nesėkmingo žygio $1664 \mathrm{~m}$. kovą ${ }^{50}$. Kariuomenès naudotų žirgų kainas rodo husaro A. D. Skorobohato bendravimo su Lietuvos didžiuoju etmonu ir vèliavos rotmistru M. K. Pacu atvejis. 1669 m. būdamas Varšuvoje husarų draugas padovanojo etmonui iš valdovo prieš tai dovanų gautą žirgą. Iš M. K. Paco mainais jis gavo turkišką eržilą, kurị minejjo Varšuvoje netrukus pardavęs už pusantro tūkstančio auksinų ${ }^{51}$. Žinoma, ne visi žygyje reikalingi žirgai buvo tokie brangūs. Vežimus su husarų ginklais, šarvais, ekipuote ir likusia manta traukiantys arkliai taip pat kainavo kur kas pigiau. J. V. Počobutas Odlanickis prasitare $1661 \mathrm{~m}$. praradęs 60 auksinų vertą vežimui traukti skirtą žemaituką (żmujdzina $)^{52}$. Gerokai mažiau už karo žirgą buvo vertinamas ir žygio vežimas. $1661 \mathrm{~m}$. keliantis per Drisą dabartinejje Baltarusijoje nuo aukšto kranto ị upę i krito ir nuskendo pusantro šimto auksinų husaro ịvertintas vežimas ${ }^{53}$.

\section{ŽYGIS, GYVENIMAS STOVYKLOJE IR DVIKOVOS}

Husarai buvo prestižinè tautinio autoramento ir visos kariuomenès dalis. Tarnybą jų daliniuose bajorai laikė garbės ir pripažinimo lydimu pasirinkimu. Valdovas ir etmonai didžiavosi savo husarų vèliavomis ir tai akivaizdžiai demonstravo. Tačiau pačių kavaleristų atsiminimai parodo ir kitą karo pusę. Jie supažindina su žygių eiga, jų metu kylančiais sunkumais ir pavojais. XVII a. karių gyvenimas stovykloje, pertraukos tarp mūšių ir operacijų buvo ir su karo veiksmais bei tiesioginėmis karių pareigomis nesusijusių veiksmų metas.

Visą XVII a. husarai buvo laikomi mūšio baigtị nulemti galinčia karine jèga ir kartu privilegijuota, aristokratiška, pasididžiavimo verta formuote. Šių sunkiųjų kavaleristų galios patvirtinimas buvo ir jiems teikiamos reprezentacinès funkcijos bei progos būti šalia etmonų ar net paties valdovo.

Husarai dalyvaudavo iškilmèse ir mirusių didikų, svarbių pareigūnų

\footnotetext{
50 A. D. Skorobohaty, Diariusz, oprac. T. Wasilewski, s. 102.

51 Ten pat, s. 118-119.

52 J. Wł. Poczobut Odlanicki, Pamiętnik 1640-1684, oprac. A. Rachuba, s. 150.

53 Ten pat, s. 166.
} 
laidotuvių apeigose ${ }^{54}$. Nuostabą ir baimę keliančios ceremonijos metu, pagerbiant mirusiji, raitas husaras bažnyčioje turẻdavo sulaužyti ieti. Svarbą jo vaidmeniui teatralizuotuose apeigose suteidavo tai, kad būtent jis buvo tapatinamas su mirusiuoju ${ }^{55}$. Tikètina, kad atlikti ši vaidmeni turẻdavo ne tik patyrę, bet ir gerbiami, pripažinti kavaleristai. A. D. Skorobohatas minejjo Lietuvos didžiojo etmono nurodymu ilgają husarų ieti sulaužęs (kruszyłem kopija) 1668 m., pagerbiant mirusį LDK pakanclerị Aleksandrą Kristupą Naruševičių (Aleksander Krzysztof Naruszewicz), vasarị tai padaręs dar kartą Gardino bernardinų bažnyčioje pagerbiant poną Buchoveckị (Buchowiecki) $)^{56}$. Dalyvauti laidotuvese ir sulaužyti ietị jam teko ir vèliau, pavyzdžiui, $1670 \mathrm{~m}$. rugpjūtị Vilniaus Šv. Stanislovo bažnyčioje, LDK kanclerio Kristupo Paco (Krzysztof Pac) prašymu pagerbiant amžinybėn iškeliavusị LDK pastalininkį Joną Samuelị Pacą (Jan Samuel Pac), Dominyką Pacą (Dominik Pac), Ašmenos maršalką Joną Vladislovą Despotą-Zenovičių (Jan Władysław Despot Zenowicz). Kaip rodo atsiminimai, $1671 \mathrm{~m}$. husaras vèl buvo paprašytas dalyvauti laido-

\footnotetext{
${ }^{54}$ Kai kuriais atvejais mirusių didikų pagerbimo apeigos vykdavo praëjus nemažai laiko po šių asmenų mirties. Jas sieti galima su perlaidojimu ar pervežimu ị mauzoliejų.

${ }^{55}$ Baroko epochoje Lenkijos karalystės ir Lietuvos diduomenès laidotuvių papročių dalimi tapo ieties laužymas bažnyčioje. Laikantis sarmatiškų papročių, pompastiškose laidotuvėse dalyvaudavo grupè raitelių, kurie, vilkẻdami šarvus ir prabangią aprangą, jodavo procesijos priešakyje nešini mirusio asmens veiklą ar pareigas rodančiais atributais - ietimi, kardu, palašu, vèliava, bunčiuku (žr. paaiškinimą). Paskui karstą buvo vedamas mirusiojo mėgtas žirgas, nešamas šyšakas (šalmas), kalavijas ir skydas. Laikantis gedulo, laidotuvių procesijoje jojantis husaras turèjo laikyti ieți, smaigaliu palenktą žemyn. Galiausiai susirinkusieji $\mathfrak{i}$ apeigas stebėdavo, kaip $\mathfrak{i}$ bažnyčią paeiliui ijoja raiteliai, kurių pirmasis sulaužo ieț̣ pataikęs prie herbinio skydo šalia mirusiojo karsto. Po to kiekvienas ijojantis raitelis prie herbo numesdavo turimą ginklą ir kitą atributą. Teatralizuotame veiksme dalyvaujantis husaras, sulaužęs ietị, turẻdavo su trenksmu kristi nuo žirgo. Parodant mirties pergalę prieš žemiškąji gyvenimą, ši veiksmą tekdavo atlikti ir kitiems raiteliams. Kartu su mirusiuoju pasibaigus ir jo giminei, laidotuvèse reikejjo sulaužyti ir jo herbą ar spaudą. W. Łoziński, Życie polskie w dawnych wiekach, Kraków, 1969, s. 214-215; Bunčiukas (angl. bunchuk, lenk. buńczuk, rus. бунчук) - azijietiškos kilmès kariuomenės ženklas arba papuošalas, pagamintas iš žirgo arba jako ašutų, suimtų i kuokštą ir pritvirtintų prie puošnaus koto su metaliniu antgaliu, pusmėnuliu ir pan. Kuokštų skaičius priklausydavo nuo užimamų pareigų arba titulo. Nuo XVII a. ATR tai buvo aukščiausios etmonų valdžios ženklas. İmautas ị puošnų tinklelị iš spalvotų arba auksinių virvučių, bunčiukas buvo kabinamas ir žirgui po kaklu.
}

56 A. D. Skorobohaty, Diariusz, oprac. T. Wasilewski, s. 107. 
tuvėse ir sulaužè ietị mirusio dignitoriaus, Gardino pakamario Stanislovo Masalskio (Stanisław Masalski) ${ }^{57}$, o 1672 m. savo giminaičio Fabijono Politalskio (Fabian Politalski) pagerbimo apeigose Gardino dominikonu bažnyčioje $\mathrm{e}^{58}$.

Ieties laužymą mini ir J. V. Počobutas Odlanickis, tačiau bent kelis kartus dalyvauti apeigose, jo žodžiai, sutrukdè aplinkybės. Rašydamas apie savo giminaičio, taip pat husarų draugo, laidotuves $1662 \mathrm{~m}$. spalị, jis paminejjo, kad Kupiškio bažnyčioje ietị sulaužè Mykolas Šykeris (Michał Szykier), kitos lauko etmono V. K. Gosevskio husarų vèliavos draugas ${ }^{59}$. Atsiminimų autoriaus žiniomis, šis mirusiojo pagerbimo atvejis vos nesibaigè nelaime. Kai visu greičiu jojęs husaras prie išejjimo iš bažnyčios vos spejjo sulaužyti ieti, jos dalis krito skersai kelio bejgančiam žirgui. Tinkamai žirgą nukreipęs husaras atsitrenkè i duris ir efektingai nukrito prie išejimo iš bažnyčios, susirinkusiems vèliau stebintis, kad apskritai liko gyvas. Aptaręs šị ne itin sėkmingą atvejị, kavaleristas paminèjo sẻkmingai ietị sulaužęs $1663 \mathrm{~m}$. vasarị, pagerbiant toje pačioje Lietuvos lauko etmono vèliavoje anksčiau tarnavusị savo giminaitị Joteiką (Jotko, Jotejko $)^{60}$. Husaras pasakojo sulaukęs didžiojo etmono prašymo sulaužyti ietị pagerbiant minètą LDK pakanclerị A. K. Naruševičių 1669 m., tačiau dèl dvikovos ir vèlesnio slapstymosi planus turèjo pakeisti ${ }^{61}$. Atsiminimu autorius minèjo $1670 \mathrm{~m}$. rugpjūti gavęs LDK kanclerio Kristupo Paco (Krzysztof Pac) prašymą sulaužyti ietis pagerbiant minètus J. S. Pacą, D. Pacą ir J. V. Despotą-Zenovičių. Neslèpdamas nusivylimo, atsiminimuose jis rašè, kad, atvykus ị sostinę, jam buvo padèkota už sugaištą laiką ir pranešta, kad bus sulaužytos ne trys, o tik viena ietis ${ }^{62}$. Kaip matėme, sulaužęs ietis pagerbiant A. K. Naruševičių, vèliau J. S. Pacą, D. Pacą, ir J. V. Despotą-Zenovičių minèjo kitas husaras ir atsiminimų autorius A. D. Skorobohatas.

57 Atsiminimų autorius datavo ši ịvyki klaidingai - $1670 \mathrm{~m}$. rugpjūčio $15 \mathrm{~d}$. Kiti šaltiniai rodo, kad Stanislovas Masalskis mirè 1670 m. lapkričio 7 d. Jei mėnuo ir diena atsiminimuose nurodyti teisingai, pagerbiant mirusijji ietis galejo būti sulaužyta $1671 \mathrm{~m}$. rugpjūčio $15 \mathrm{~d}$. Ten pat, s. 120-121.

58 Ten pat, s. 121.

59 J. Wł. Poczobut Odlanicki, Pamiętnik 1640-1684, oprac. A. Rachuba, s. 174.

60 Ten pat, s. 180.

61 Ten pat, s. 239.

62 Ten pat, s. 252-253. 
1668 m. ívykusio Jono Kazimiero vizito metu husarui A. D. Skorobohatui buvo suteikta gerbè padovanoti dèmètą medžioklinị šunị ir gauti iš jo kavaleristų itin vertinamą dovaną - žirgą, kurị, kaip minèta, kitais metais jis iškeite i̇ didžiojo etmono M. K. Paco turkišką žirgą ${ }^{63}$. Bendravimas su valdovu ir etmonu, keitimasis dovanomis taip pat pabrèždavo husarų elitinị statusą kariuomenèje, priklausymą Lietuvos aristokratijai, artumą dignitorių sluoksniui ir jų pripažinimą ATR aukščiausiosios vadovybès. Be abejo, senas bajoriškas tradicijas atskleidžiantis medžioklinio šuns ar žirgo dovanojimas buvo dar viena atsidavimo vadovybei (valdovui ir etmonui) išraiškos forma. Mirusiụjų pagerbimo pavyzdžiai rodo ir LDK diduomenès tapatinimąsi su husarais - riterių luomo karingąja dalimi, geriausiai ịkūnijančia ir saugančia jos tradicijas.

Žygyje, taip pat ir stovykloje karių laukè daugybė pavojų. Nuo jų nebuvo apsaugoti ir rinktinių kariuomenès dalinių kariai. Vienas rimčiausių pavojų buvo karių sveikatai ir gyvybei grésmę kèlusios ligos ir žygyje ar mūšyje patirti sužeidimai. XVII a. medicina nebuvo pajẻgi užtikrinti tinkamo sergančių arba sužeistų karių gydymo ir būtinos skubios pagalbos. Tuometè medicinos tarnyba Karūnos ir LDK bei kitų valstybių kariuomenèse dar nebuvo išvystyta. Karių mirtingumas žygio sąlygomis buvo didelis. Husarų mirtingumą didindavo ir itin pavojingos šiai kavalerijos formuotei skiriamos užduotys. Jų neaplenkdavo ligos. Nenuostabu, kad tarnaujant kavalerijoje dažnai pasitaikydavo su mūšiais nesusijusių sužeidimų. Žinių apie tai randame abiejų lietuvių kavaleristų atsiminimuose. $1660 \mathrm{~m}$. Lietuvos kariuomenei žygiuojant iš Bauskès po nepasisekusios apsiausties, jodamas žirgu J. V. Počobutas Odlanickis, ił savo husariško balno lankus atsitrenkęs, itin smarkiai susižeidè stuburą (szwankowałem tak sprośnie z kokiem, że oba lęki usarskie złamały się o grzbiet mój) ir ištinus kaklui sunkiai negalavo ${ }^{64} .1661 \mathrm{~m}$. husaras prarado nuo savaitę trukusios karštligès mirusi palydos raitelị Kučinską (Kuczyński) ${ }^{65}$. Elitinėje husarų vèliavoje tarnaujantis A. D. Skorobohatas prasitarè, kad vos mirties išvenge pačioje $1667 \mathrm{~m}$. pradžioje ${ }^{66}$. Jis rašè susižeidęs žygyje $1683 \mathrm{~m}$. gruodị ir dar kartą $1684 \mathrm{~m}$. vasarị ir toliau sunkiai sirgdamas namie vos

\footnotetext{
63 A. D. Skorobohaty, Diariusz, oprac. T. Wasilewski, s. 107, 118-119.

64 J. Wł. Poczobut Odlanicki. Pamiętnik 1640-1684, oprac. A. Rachuba, s. 137.

65 Ten pat, s. 151.

66 A. D. Skorobohaty, Diariusz, oprac. T. Wasilewski, s. 106,
} 
išvengè kojos amputacijos tų pačių metų kovą. $1684 \mathrm{~m}$. vasario nesèkmes lydèjo ištikimo tarno Žukausko (Żukowski) mirtis ${ }^{67}$.

Kariuomenès elitui priklausančių husarų vèliavų draugai puoselëjo bajorų luomo vertybes ir tradicijas. Akivaizdu, kad bajoriška garbės samprata neleisdavo nuolaidžiauti arba lengvai atleisti ižzeidejjams. Tai vertẻ rizikuoti savo sveikata ar gyvybe. Dvikovoje parodyta drąsa ir meistriškumas padedavo dalinyje ịtvirtinti savo statusą.

Husarų vèliavos draugo J. V. Počobuto Odlanickio užrašuose gausu dvikovų paminejimų. Anot atsiminimų autoriaus, kautis teko ir su savo, ir su kitų husarų vèliavų draugais. Dvikovų būta tiek kariuomenès stovykloje, tiek iš jos išvykus, kai vèliava tiesiogiai nedalyvaudavo karo veiksmuose. Štai, 1660 m. rugsèji vykstant karui su Rusija, gynybai parengtoje stovykloje prie Basios upès ${ }^{68}$ ginčas dèl vietos rejestre (registre) tapo J. V. Počobuto Odlanickio ir Kazimiero Jurevičiaus (Kazimierz Jurewicz) dvikovos kardais priežastimi. Tą kartą nuo kraujo praliejimo dvikovininkus sulaikè kitų vèliavų draugai ${ }^{69}$. Priešininko nuostolius sudarè nukirsta jo kardo kryžma. Atsiminimų autoriaus žodžiais, ši dvikova padejo jam išsaugoti vietą rejestre ir pelnè nedraugų pagarbą. Kai kurios dvikovos kildavo dèl atsitiktinių dalykų. 1662 m. gruodị Alytuje vykusios vakaronès metu kilęs konfliktas peraugo ị J. V. Počobuto Odlanickio dvikovą su Lietuvos kanclerio Kristupo Zigmanto Paco husarų vèliavos draugu Mykolu Rajeckiu (Michał Rajecki) ${ }^{70}$. Dažniausiai dvikovininkai kaudavosi kardais, tačiau kartais raiteliams ịprastu būdu naudodavo pistoletus. Didžiausia tikimybè, kad šūviais iš pistoletų apsikeista $1665 \mathrm{~m}$. liepos 12 d. Kupiškyje. Dvikovų nevengusio husaro žodžiais, tądien $\mathfrak{i}$ ji šovè, bet nepataikè Lietuvos kanclerio husarų vèliavos draugas Bogdanas Aleksandravičius (Bohdan Alexandrowicz). Atsakomasis šūvis pakirto oponento žirgą ${ }^{71}$. Paminètas ir atvejis, kai kitų husarų draugų dvikova baigèsi mirtimi. J. V. Počobuto Odlanickio liudijimu, $1663 \mathrm{~m}$. liepos $20 \mathrm{~d}$. nuo husarų draugo Mykolo Skirmanto (Michał Skirmont) rankos žuvo

67 Ten pat, s. 140-141.

68 Basios (Бася) upė yra dabartinèje Baltarusijoje, Mogiliavo srityje.

69 J. Wł. Poczobut Odlanicki. Pamiętnik 1640-1684, oprac. A. Rachuba, s. 139.

70 Ten pat, s. 179.

71 Ten pat, s. 215. 
toje pačioje husarų vèliavoje tarnavęs draugas Kaunackis (Kownacki) $)^{72}$. Imanoma, kad XVII a. visuomenès bajoriškosios dalies kultūros kontekste pastarojo husaro dvikovų istorija nebuvo išimtinè. Tačiau buvo ir dvikovomis santykių problemas spręsti nelinkusių karių. Prie jų priskirtume A. D. Skorobohatą, husaru tapusị brandesnio amžiaus (26 metų). Galbūt nenoras rašyti apie dvikovas, o gal charakterio ypatumai, auklejimas ar ìsitikinimai lèmé tai, kad pastarojo kario atsiminimuose beveik neminimos kovos dèl garbès. Šio Lietuvos kariuomenès husaro dvikovos aprašymas yra reta išimtis. Atsiminimuose A. D. Skorobohatas prasitarè, kad $1689 \mathrm{~m}$. gegužès $1 \mathrm{~d}$., kai pats husarų vèliavoje jau netarnavo, vienas iš jo namuose besisvečiuojančių karių liepe tarnui pavogti muškietą, kurią jèga susigrąžinus kilo konfliktas. Gegužès 3 d. ryte nedraugas iškvietè atsiminimų autorių iš bažnyčios į dvikovą ${ }^{73}$.

Grįžtant prie karių gyvenimo stovykloje ir žygio metu, verta paminèti, kad, be dvikovų, kariuomenès stovykloje įvykdavo ir kitokio pobūdžio incidentų. J. V. Počobuto Odlanickio liudijimu, $1660 \mathrm{~m}$. pavasari antrosios V. K. Gosevskio husarų vèliavos draugą Steponą Pšistanovskị (Stefan Przystanowski) nužude kitu karių tarnai. Mirties bausmè kaltiesiems ivykdyta Baisogaloje ${ }^{74}$. Sunkiojo kavaleristo atsiminimuose užsimenama ir apie jų palydoms priklausiusių žmonių pabėgimo iš dalinio atvejus. Štai $1660 \mathrm{~m}$. rugpjūčio $25 \mathrm{~d}$. jis paminèjo pabègus savo tarnus ${ }^{75}$.

Aprašant judèjimą žygių metu dažniausiai apsiribojama bendro pobūdžio žiniomis, nurodant judejjimo kryptis ir laiką. J. V. Počobuto Odlanickio atsiminimuose aprašytas $1663 \mathrm{~m}$. pabaigos-1664 m. pradžios Lietuvos ir Lenkijos kariuomenių žygis ị Rusiją - išimtis. Juose pateiktas palyginti detalus netipiško, visomis prasmèmis žiauraus ir itin sunkaus žygio aprašymas. Atsiminimų autoriaus liudijimu, žygio metu nepavykus užimti priešo ginamo Roslavlio ịtvirtinimų, kariuomenės nužygiavo prie Briansko, vèliau - prie Sevsko ${ }^{76}$. Husaras pamini, kad sausio 14 d., ižen-

\footnotetext{
2 Ten pat, s. 182.

73 A. D. Skorobohaty, Diariusz, oprac. T. Wasilewski, s. 148-149.

74 J. Wł. Poczobut Odlanicki. Pamiętnik 1640-1684, oprac. A. Rachuba, s. 137.

75 Ten pat, s. 138.

76 Ten pat, s. 186-188, 190-193; J. Janowski, Aleksander Hylary Połubiński. Działalność wojskowa w latach 1650-1665, Przegląd Historyczno-Wojskowy, Tom X, Warszawa, 1938, s. 185-186.
} 
gus pusantros mylios ị Rusijos teritoriją, Lietuvos lauko etmonas Mykolas Kazimieras Pacas suteikè „leidimą deginti ir pjauti“ (licencyja palić $i$ ścinać $)^{77}$. Tą dieną apie penkias mylias nužygiavusios pajègos, ịskaitant husarus, ketino apsistoti nakvynei, bet gavo nurodymą naktị nužygiuoti dar penkias mylias. Pasiekusios numatytą vietą, čia praleido naktị ir visą dieną ${ }^{78}$. J. V. Počobutas Odlanickis vaizdingai aprašè $1664 \mathrm{~m}$. kovo pradžioje (ménesio 1 arba 3 d.) ìvykusị susitikimą su valdovu Jonu Kazimieru $^{79}$, apžiūrint per Desnos upę statomą perkèlą. Minimas kariuomenei saugiai persikelti ị kitą upès krantą statomas tiltas ant valčių. Su caro pajègomis planuota susiremti kitame krante.

Atsiminimuose jaučiama husaro kritika karinių gabumų neturinčio Jono Kazimiero planui ir pritarimas Karūnos bei LDK kariuomenių vadovybei, bandančiai karalių nuo jo atkalbèti. J. V. Počobuto Odlanickio liudijimu, galiausiai „vargais negalais jo malonybę karalių nuo to sumanymo atkalbejo, už ką šlovė Aukščiausiajam, nes tikrai kariuomenè būtų pražuvusi tame tankiame miške, kur norejo panaudoti husarus, $\mathfrak{i}$ kuriuos visos viltys dètos“" ${ }^{\text {“ }}$.

A. D. Skorobohato atsiminimuose randame skirtingomis sąlygomis vykusių žygių aprašymų. Vienuose autorius užfiksavo spartų savo husarų vẻliavos ir kitų LDK kariuomenès dalinių judejjimą, kituose pateikė užsitęsusių, nesklandžiai vykusių žygių atvejus. Štai 1678 m. spalį M. K. Paco husarų vèliava be gurguolès sparčiai žygiavo pasitikti prie Prūsijos artejjančius švedus ${ }^{81}$. Visiškai kitaip atrodo gana nuodugniai aprašytas 1683 m. žygis. Husarų vèliava, kurios rotmistru mirus M. K. Pacui tų metų pavasarị tapo pats Jonas Sobieskis, atsiminimų autoriaus žiniomis, pajudejo iš Anykščių 1683 m. rugsėjo 9 d. Rugsèjo 20 d., kai vèliava persikèlè per Nemuną prie Kauno, jau buvo praejjusi savaitė po valdovo vadovaujamos Karūnos kariuomenès ir Šventosios Romos imperijos pajėgu pergalès prie Vienos (rugsèjo $12 \mathrm{~d}$.). Besitęsiant Lietuvos kariuomenès žygiui, rugsèjo $22 \mathrm{~d}$. dalinị kuriam laikui palikęs A. D. Skorobohatas išvyko namo ir čia spalio $3 \mathrm{~d}$. prièmé savo husarų vẻliavos poručniką ir

\footnotetext{
77 J. Wł. Poczobut Odlanicki, Pamiętnik 1640-1684, oprac. A. Rachuba, s. 188.

78 Ten pat, s. 190.

79 Ten pat, s. 200.

80 Ten pat, s. 200-201.

81 A. D. Skorobohaty, Diariusz, oprac. T. Wasilewski, s. 130.
} 
draugus. Atsiminimų autorius minèjo išvykęs paskui vèliavą spalio $7 \mathrm{~d}$., o spalio 9 d. pavijęs ją prie Suražo (Suraż) Palenkejeje ${ }^{82}$. Husarų dar laukè tolimesnis žygis per Lenkijos karalystę. Atsiminimuose pažymèta, kad lapkričio $18 \mathrm{~d}$. vẻliava pasiekè Lvovo prieigas, o lapkričio $25 \mathrm{~d}$., gavusi nurodymą, naktị žygiavo be gurguolès, kuri išsiųsta prisijungè prie Karūnos kariuomenès. Tą pačią naktị husarų vèliava jau turejjusi nakvoti prie Podolès Kameneco. Lapkričio 26 d. A. D. Skorobohatui judant su priešakine sargyba, lietuvių ir lenkų kariuomenès susijungè, o lapkričio $27 \mathrm{~d}$. ịrengè stovyklą apsnigtuose laukuose ${ }^{83}$. Jau kitą dieną husarų ir kitų Karūnos ir LDK pajègų laukè susidūrimas su priešu.

Husarų tekstai byloja, kad kai kuriais atvejais laukti mūšio buvo itin sunku. Rašydamas apie kovas su švedais Kurše 1659 m., J. V. Počobutas Odlanickis apibūdino spalio $18 \mathrm{~d}$. pavojaus signalą ir pasiruošimą susidūrimui su priešu. Tuomet, atejus žiniai apie artẻjančius R. Douglaso vadovaujamus Švedijos kariuomenès dalinius su artilerija, lietuvių kavaleristo liudijimu, jis su bendražygiais apsiginklavo kaip mūšiui, išsidèstė kovos rikiuote ir ją išlaikè nuo vidurdienio iki nakties blogomis oro sąlygomis - maišantis pirmam tą rudenį sniegui su lietumi. Vèliau, taip ir nesulaukusi švedų puolimo, kariuomenè paliko užimtą lauką ${ }^{84}$.

1663-1664 m. žygyje prieš caro kariuomenę rikiuotèje stovèta ir naktimis. Atsiminimuose husaras J. V. Počobutas Odlanickis prasitarè apie sunkias sąlygas. Kariai kente alkị ir šalți, o pasibaigus pašarui, savo žirgus kavaleristams teko šerti lapuočių žieve ${ }^{85}$. Panašias sąlygas, aprašydamas $1673 \mathrm{~m}$. Chotyno kampaniją, paminèjo ir A. D. Skorobohatas. Anot atsiminimų autoriaus, tų metų lapkričio $9 \mathrm{~d}$. Karūnos ir Lietuvos kariuomenès rengési mūšiui smarkiai apšaudomos apkasuose ịsitvirtinusių turkų artilerijos. Atsitraukusiai per ketvirtị mylios Lietuvos kariuomenei teko nakvoti be vežimų ir ugnies. Sunkių žygio sąlygų nepalengvino ir pergalè mūšio lauke. Apie sunkumus prie Chotyno husaras raše ir apibūdindamas padètị ịveikus turkus. Lapkričio antrojoje pusèje pasidavus turkų užimtai tvirtovei, prie jos kartu su likusia kariuomene stoveję kavaleristai turejjo skubiai parūpinti savo žirgams pašaro, kurio visai nebebuvo likę

\footnotetext{
82 Ten pat, s. 135-136.

83 Ten pat, s. 138-139.

84 J. Wł. Poczobut Odlanicki, Pamiętnik 1640-1684, oprac. A. Rachuba, s. 131.

85 Ten pat, s. 204.
} 
dèl gausiai iškritusio sniego ${ }^{86}$.

Husarų vèliavos sudètyje 1659-1660 m. Kurše vykusiose kovose su švedais ir vèlesnèse kovose su Rusija LDK teritorijoje bei už jos ribų dalyvavęs J. V. Počobutas Odlanickis gana išsamiai aprašè priešo užimtų pilių apgulas. Atsiminimuose jis palyginti daug vietos skyrè Lietuvos kariuomenès kairiojo sparno (Žemaitijos divizijos) 1659-1660 m. vykdytai Bauskès apgulai. Joje kartu su kitais kavalerijos, pėstininkų daliniais ir artilerija dalyvavo ir atsiminimų autorius su husarų vèliava. Rašydamas apie apgulą, kavaleristas išskyrè ką tik ị miestą atvykusios (1659 m. spalio 27 d.) savo husarų vèliavos naktinị budejimą prie pilies, pagrindinès kariuomenès dalies, ịskaitant pèstininkus, atvykimą (1659 m. lapkričio 2 d.) ir apgulai vadovavusio Mykolo Kazimiero Paco skyrimą regimentoriu$\mathrm{mi}^{87}$ (1659 m. lapkričio 5 d.). Husaras paminejo ir savo apsilankymą namuose (1659 m. lapkričio 10-gruodžio 16 d.) siekiant aprūpinti stovykloje ịsigytą palydą, vèlesnị grịžimą ị kariuomenę prie Bauskès, kur šventė Kalèdas ${ }^{88}$. Paminètas tais pačiais metais (1659 m. gruodžio 30 d.) įvykęs švedų igulos išpuolis, kurio metu žuvo 6 karininkai su pèstininkais ${ }^{89}$.

Sẻkmingi lietuvių dalinių veiksmai ir kitų švedų kontroliuotų tvirtovių užèmimas buvo optimizmo Bauskę apgulusiems daliniams teikusios naujienos, tačiau užimti priešo atkakliai ginamos pilies jie negalejo. J. V. Počobuto Odlanickio žiniomis, tęsdami apsiaustị, $1660 \mathrm{~m}$. vasario 20 d. lietuviai iš keturių pusių apšaude pili iš patrankų ir mortyrų, ištisą dieną bombarduodami priešą didelès galios sviediniais (artilerijos granatomis ar bombomis $)^{90}$, veiksmų nenutraukè ir nakti, tačiau igulos pasiduoti neprivertè (bili nasi ze czterech stron $z$ dział i moździerzów, granaty potężne rzucano cały dzień, nawet $i$ w nocy nie dawano im pokoju,

\footnotetext{
86 A. D. Skorobohaty, Diariusz, oprac. T. Wasilewski, s. 122-123.

87 Regimentorius (lenk regimentarz) - laikinas kariuomenès vadas, paprastai skiriamas etmonui patekus $\mathfrak{i}$ nelaisvę arba jei po etmono mirties $\mathfrak{i}$ jo pareigas kurị laiką nebuvo paskirtas kitas asmuo. Teise skirti regimentorių, kuriam patikėdavo vadovavimą kariuomenei, Lenkijos ir Lietuvos valdovas naudodavosi ir tada, kai siekdavo sumažinti kurio nors etmono ịtaką ginkluotosiose pajègose ir valstybèje.

88 J. Wł. Poczobut Odlanicki, Pamiętnik 1640-1684, oprac. A. Rachuba, s. 134-135.

${ }^{89}$ Ten pat, s. 135.

90 Artilerijos granatos (lenk. granaty artyleryjskie) - sprogstamieji artilerijos sviediniai, XVII-XIX a. naudoti priešo gyvajai jègai naikinti ir ịtvirtinimams griauti. Didesnio kalibro sprogstamiesiems artilerijos sviediniams prigijo bombų pavadinimas.
} 
co im nic snać nie szkodziło, kiedy nie pomyśleli o traktatach). Po to, kai $1660 \mathrm{~m}$. kovo $7 \mathrm{~d}$. sudegè nemaža miesto dalis, kurioje buvo įsikūrusi poručniko Kazimiero Žeromskio (Kazimierz Żeromski) vadovaujama kita lauko etmono husarų vèliava, pagrindiniai Lietuvos kariuomenès kairiojo sparno daliniai atsitraukè nuo neužimtos Bauskès pilies. Prie jos sienų, husaro žiniomis, lietuviai neteko šimto keliolikos pėstininkų ir trijų kapitonų ${ }^{91}$. Rašydamas apie švedų igulos išéjimą iš Bauskès, sudarius $1660 \mathrm{~m}$. gegužès 3 d. Olyvos taikos sutartị, atsiminimų autorius paminèjo, kad šios nedidelès pilies tinkamumą gynybai užtikrino jos padèties ypatumai. Daug laiko apguloje praleidęs husaras teigè, kad po pilimi, pastatyta ant uolètos kalvos, Mūšos ir Nemunèlio upių santakoje, nebuvo galima pasikasti ${ }^{92}$.

Kaip matome iš J. V. Počobuto Odlanickio atsiminimų teksto, LDK kariuomenès Žemaitijos divizijos husarų patirtị praplètė ir dalyvavimas rusų užimtos Vilniaus pilies apguloje ${ }^{93}$. Kavaleristo žiniomis, LDK sostinę $1660 \mathrm{~m}$. liepos $13 \mathrm{~d}$. pasiekę V. K. Gosevskio husarų vèliavos kariai buvo netrukus įvykusio priešo naktinio išpuolio ir mènesio pabaigoje surengto pilies šturmo liudininkai. Liepos 31-osios naktị puolančius lietuvius caro kariai, kaip teigè husaras, atmušè panaudoję ore paskleistą nuodingąją priemonę, kuri nužudè ir sužalojo apie septynis šimtus žmonių. Atsiminimų autorius teigè, kad pastaroji priemonè paveike ir jo husarų vèliavą. Rašydamas apie tolesnę i̇vykių eigą, J. V. Počobutas Odlanickis paminëjo M. K. Paco vadovaujamo Lietuvos kariuomenès kairiojo sparno pagrindinių pajègų (taip pat ir jo husarų vèliavos) atitraukimą nuo Vilniaus ir jų žygị $\mathfrak{i}$ dabartinès Baltarusijos teritoriją suprasdamas, kad jos turèjo paremti didžiojo etmono P. Sapiegos dešiniojo sparno veiksmus prieš caro

\footnotetext{
91 J. Wł. Poczobut Odlanicki, Pamiętnik 1640-1684, oprac. A. Rachuba, s. 136.

${ }_{92}$ Ten pat, s. 137.

931660 m. Vilniuje ir Kaune esančios Rusijos kariuomenès igulos buvo rimta kliūtis vaduojant okupuotą Lietuvos teritoriją ir užtikrinanti išvaduotos dalies saugumą. Savo išpuoliais šiuose miestuose esantys caro kariuomenès daliniai ne tik niokojo artimiausias vietoves, bet ir kèlè grèsmę išlaisvintos Žemaitijos pavietams. Iš Vilniaus, Kauno ir Gardino siunčiamos priešo karių grupès plešdavo bajorų valdas, atimdami maistą ir pašarą. Kai kuriais atvejais bajorai ir valstiečiai buvo žudomi, o jų sodybos deginamos. Žiaurūs išpuoliai turejo atgrasyti bajorus nuo pagalbos Lietuvos kariuomenès daliniams ir buvo svarbūs aprūpinant caro kariuomenès igulas maistu bei pašaru rengiantis laukiamai blokadai. K. Kossarzecki, Kampania roku 1660 na Litwie, s. 286-289.
} 
kariuomenę. Atsiminimuose jis prasitaré apie blokuoti Vilniaus pilies paliktus Lietuvos kariuomenès reitarus, pėstininkus ir totorių vèliavas ${ }^{94}$.

\section{MŪŠIAI}

XVII a. Karūnos ir LDK husarai buvo sunkiosios kavalerijos rūšis, skirta priešo rikiuotei mūšio lauke pralaužti. Puolantys sunkiai ginkluoti kavaleristai atlikdavo sudettingus manevrus, glausta rikiuote artèdavo link priešo paleidę žirgus šuoliais. Kartais, vadovybei derantis su priešu, laukti mūšio pradžios reikèdavo ilgai. Kitais atvejais mūšis prasidèdavo netikètai, užklupus priešui arba stengiantis jị užklupti. Kai kada laukiamas mūšis galëjo apskritai neịvykti.

Pažvelgę i XVII a. pirmosios pusès mūšius nesunkiai įžiūrèsime husarų taktini pranašumą prieš priešo kavaleriją ir pėstininkus. Šị pranašumą nusako ir mūšiuose su turkais bei švedais dalyvavę kavaleristai.

1621 m. prie Chotyno puolančią turkų kariuomenę kontratakavusiai husarų vèliavai vadovavęs Jonas Rudamina apibūdino artẻjančius sultono karius kaip grakščius, brangią aprangą vilkinčius ir savo jẻgomis pasitikinčius raitelius. Taip apibūdintiems spahiams ir kitiems rinktiniams sultono raiteliams atremti husarų vèliavos rikiuodavosi dviem eilèmis ${ }^{95}$. Šiose kautynèse iečių neturintys Rudaminos husarai, registruose vadinami reitarais, patyre daug nuostolių, tačiau kartu su kitomis trimis husarų vèliavomis parbloške turkų kavaleriją ir janyčarus bei privertẻ juos greitai pasišalinti iš mūšio lauko. Rašydamas apie šio susidūrimo padarinius Rudamina minèjo stulbinantị psichologinį efektą - Osmanų pajègos daugiau nedriso pulti sunkiosios kavalerijos ginamų pozicijų ${ }^{96}$.

Husaro Jono Kunovskio (Jan Kunowski) reliacijoje aprašyta elitinio Gustavo II Adolfo kirasyrų eskadrono kova su Aleksandro Korvino Gosevskio husarų vèliava prie Kropimoizos ežero. Eiliuotame tekste J. Ku-

\footnotetext{
94 J. Wł. Poczobut Odlanicki, Pamiętnik 1640-1684, oprac. A. Rachuba, s. 138; K. Kosažeckio pateiktais duomenimis, Vilniaus pilyje esančiai rusų igulai blokuoti buvo palikti Kazimiero Žeromskio vadovaujami pèstininkai, reitarai, dragūnai ir dvi totorių vėliavos. K. Kossarzecki, Kampania roku 1660 na Litwie, s. 296.

95 XVII a. ịprastą Lenkijos ir Lietuvos kariuomenių husarų vèliavos rikiuotę mūšyje sudarydavo trys kavaleristų eilès.

96 R. Sikora, Niezwykłe bitwy i szarże husarii, s. 62.
} 
novskis nurodè, kad per susidūrimą tankiai išsirikiavę švedų kavaleristai apšaudè husarus taikydami šiems ị veidą ir kaklą. Švedų kirasyrai kovèsi kitaip nei Karolio IX reitarai Salaspilio (Kircholmo) mūšio lauke. Po sumaišti keliančios kovos kirasyrai atsitraukdavo, persirikiuodavo ir vèl atakuodavo. Tai kartojosi kelis kartus. Kunovskio eilès kalba apie tai, kad galiausiai husarų atmušti švedų kirasyrai atsitrauké $\dot{e}^{97}$. Švedų pistoletų ugnis buvo nepakankamai efektyvi, akivaizdu, kad kovoje šaltaisiais ginklais LDK sunkioji kavalerija juos vis dar pranoko.

Geba išlaikyti iniciatyvą mūšyje ir taktinis pranašumas priešo kariuomenès atžvilgiu atskleista husarų tekstuose ir XVII a. antrojoje pusèje, tačiau užfiksuoti ir visai Lietuvos, taip pat Karūnos kariuomenei gero nežadantys pokyčiai. Tai ypač gerai rodo susidūrimų su Rusijos kariuomene aprašymai, kuriuose pabrèžiama išaugusi priešo artilerijos pabūklų ir pėstininkų muškietų ugnies galia.

1655 m. rusų užimto Mogiliavo šturme dalyvaujančios kavalerijos vèliavos, kartu ir husarai, miestą pasiekė užšalusia Dniepro upe. Puolime dalyvaujanti husarų vèliava, kurioje tarnavo Kristupas Vorbekas-Letovas, anot reliacijos, buvo smarkiai („negailint parako ir kulkų“) apšaudyta nuo aukštutinio (senojo) miesto pastatų ir statinių (aštriakuolių) tvo$\operatorname{ros}^{98}$. Laiške tèvui jis rašè, kad prie miesto lietuvių kavaleristus pasitiko pro vartus pabirę rusų pėstininkai - muškietininkų ir pikinierių formuotè bei kazokai. Lauko etmono V. K. Gosevskio įsakymu husarai ryžtingai (resolute) atakavo caro pèstininkus, kurie juos pasitiko muškietų salvèmis $^{99}$, tačiau taip sustabdyti nesugebèjo. Priešo eiles pasiekę husarai sulaužè savo ietis ir, K. Vorbeko-Letovo žodžiais, išsitraukę palašus, arba kardus $^{100}$, èmé persekioti $\mathfrak{i}$ viršutini miestą besitraukiančius rusų karius ir kazokus. Reliacijoje aiškiai parodyta, kad pirmasis husarų smūgis ietimis ir kardais pralaužè priešo rikiuotę, tačiau mėginant toliau šturmuoti Mogiliavą sèkmé nuo LDK karių nusisuko.

I žemutinị miestą kavaleristai pateko pro ji juosiančioje statinių tvo-

\footnotetext{
97 Ekspedycyja inflantska 1621 roku, s. 131-133.

98 Kristupo Vorbeko-Letovo laiškas Motiejui Vorbekui-Letovui, M. Vorbek-Lettow, Skarbnica pamięci, s. 218.

99 Ten pat, s. 219.

${ }^{100}$ Gali būti, kad Kristupo Vorbeko-Letovo laiške palašais vadinami kardai. Pagal istorinę tradiciją husarų kardai kartais buvo vadinami palašais arba husarų palašais.
} 
roje padarytą siaurą išlaužą, tinkamą žirgams praeiti. İ miestą prasibrovė V. K. Gonsevskio husarų ir kazokų (šarvininkų) ${ }^{101}$ vèliavų bei Naugarduko vèliavininko Stepono Franckevičiaus (Stefan Frąckiewicz) Naugarduko pavieto husarų vèliavos kariai (apie 150 žirgų) ${ }^{102}$. Staigi rusų pikinierių ir muškietininkų ataka atkirto dalị i miestą patekusių kavaleristų nuo anapus įtvirtinimų likusių bendražygių. Tarp atkirstųjų buvo K. Vorbeko-Letovo vèliava. Laiške tèvui jis minejo, kad, nesitikèdami laiku sulaukti pagalbos ir prasimušti pro artimiausius vartus, kavaleristai susiskirste $\mathfrak{i}$ vèliavas ir pasileido žemutinio miesto gatvėmis veikdami trimis grupèmis. Išejjimo iš miesto ieškantys LDK kavaleristai buvo intensyviai, kulkoms skriejant kaip krušai, apšaudomi iš namų, puolami pikemis, trumpesnèmis kazoku ietimis ir bardišiais (Srodze gęsta strzelbq rażono nas $z$ domów, a mianowicie w ciasnych zawułkach, że kule jako grad lecieli, a co spisami, z oszczepami kłóli, bardyszami siekli, siła by o tym pisać) ${ }^{103}$. Mèginančius prasiveržti prie kurių nors vartų Lietuvos kariuomenès husarus ir kazokus apšaudydavo priešo kazokų šauliai ir rusų muškietininkai (srodze nas z samopałów i muszkietów okurzywali). Siaurose miesto gatvèse husarai negalejo išsiskleisti ịprasta kovos rikiuote, buvo apšaudomi iš namų, patekdavo i pikèmis, kazokų ietimis ir bardišiais puolančio priešo pasalas, bet veržèsi toliau atsišaudydami iš pistoletų. Galiausiai maždaug po trijų valandų, suradus silpniau ginamus Bychovo vartus, pavyko juos užimti ir kurị laiką išlaikyti. Vẻliau, nesant vartams išlaikyti reikalingų pèstininkų, kavaleristai atsitrauke pas saviškius ${ }^{104}$.

J. V. Počobutas Odlanickis apibūdino $1659 \mathrm{~m}$. spalio $21 \mathrm{~d}$. datuojamą mūšs su švedais prie Mūšos upès. Sparčiai judančių Lietuvos kariuomenès dalinių priešakiné sargyba sumušė nedidelę priešo grupę ir paèmė 30 karių ị nelaisvę ${ }^{105}$. Iniciatyvą išlaikantys LDK kariuomenès daliniai tęsè ịtvirtintą stovyklą ịsirengusių R. Douglaso vadovaujamų švedų pajẻgų puolimą. Husaro žiniomis, atvirame lauke su lietuviais besikaunan-

\footnotetext{
${ }^{101}$ Šaltinyje ši vėliava vadinama kozacka pancerna (kazokų šarvininkų).

102 Kristupo Vorbeko-Letovo laiškas Motiejui Vorbekui-Letovui, M. Vorbek-Lettow, Skarbnica pamięci, s. 219; R. Sikora, Niezwykłe bitwy i szarże husarii, s. 119.

${ }^{103}$ Kristupo Vorbeko-Letovo laiškas Motiejui Vorbekui-Letovui, M. Vorbek-Lettow M. Skarbnica pamięci, s. 219-220.

104 Ten pat, s. 220.

105 J. Wł. Poczobut Odlanicki, Pamiętnik 1640-1684, oprac. A. Rachuba, s. 131.
} 
čias priešo pajègas parėmė daugiau nei 600 švedų reitarų, pastiprinimo sulaukus - ir lietuvių pajegos. Kova tęsèsi iki sumaištị atnešusių sutemų, kai priešą buvo sunku atskirti nuo saviškių. Dar kartą pastiprinimo sulaukę LDK kariai, J. V. Počobuto Odlanickio liudijimu, nustūmé švedus iki apkasų, tačiau, $\mathfrak{i}$ kovą stojus priešo pėstininkams su artilerija, turejjo atsitraukti. Iš atsiminimų aiškejja, kad kovoje su priešo kavalerija V. K. Gosevskio husarų vèliava ir kiti LDK kariuomenès daliniai, visų pirma kavalerija, turèjo taktinị pranašumą ir pajègè išstumti priešą iš mūšio lauko. Husaro tikinimu, nakties tamsa lèmè minimalius priešo nuostolius ir apsaugojo nuo jų lietuvius. Jau kitą dieną R. Douglasas paliko savo įtvirtintas pozicijas ir atsitraukè ị Rygą toliau persekiojamas LDK kariuomenès ${ }^{106}$.

Tas pats atsiminimų autorius vaizdingai aprašè lietuvių ir lenkų pajègų, taip pat ir savo husarų veliavos dalyvavimą kovose su caro vaivados kunigaikščio Jurijaus Dolgorukio armija prie Basios upės $1660 \mathrm{~m}$. spalị. Rašydamas apie pagrindinị mūšs̆i i̇vykusị spalio 8 d., kai abi kovojančios pusès patyrè daug nuostolių, jis stengèsi nuosekliai perteikti šio kruvino susidūrimo eigą. Paminèti mūšio lauke išsirikiavusių Lietuvos ir Karūnos dalinių pozicijas sustiprinę lauko ittvirtinimai (5 šancais), kuriuose buvo išdèstyta artilerija ir péstininkai, ryte Lietuvos didžiojo etmono nusiųstas trimitininkas, pakvietęs J. Dolgorukị išeiti iš taboro ir stoti ị kovą atvirame lauke. Apie vidurdienį iš stovyklos išèję rusų daliniai, palaikomi 25 pabūklų ugnies, staigiai atakavo lietuvių ir lenkų pozicijas ${ }^{107}$. Atsiminimų autoriaus žiniomis, dalis lietuvių ir lenkų vèliavų gavo įsakymą pulti. Taip suskambejjus muzikai, giedant religinę giesmę (O gloriosa - $O$ pelna chwały) ${ }^{108}$ ir kviečiant ì pagalbą Švenčiausiąją Mergelę, kapeliono palaiminta kairiajame lietuvių ir lenkų sparne stovejusi V. K. Gosevskio husarų vèliava kontratakavo priešą. J. V. Počobuto Odlanickio žiniomis, patyrę nuostolių lietuvių husarai padarè caro kariuomenès rikiuotėje spragą, o vèliau, $\mathfrak{i}$ kovą stojus ir kitiems daliniams, sudavę dar vieną smūgị, i̇veike priešą ir persekiojo rusų karius iki jų stovyklos. Atsiminimuose kavaleristas prisipažino negalëjęs dalyvauti persekiojant priešą ir atsklei-

\footnotetext{
106 Ten pat, s. 132.

107 Ten pat, s. 143; Малов А. В. Московские выборные полки солдатского строя в начальный период своей истории. 1656-1671 гг. Москва, 2006, с. 456.

${ }^{108}$ O gloriosa - O pełna chwały - Marijos giesmès pavadinimas.
} 
dè savo asmeninę patirtị. Husaro žirgas buvo pašautas, parkritęs atsikèlè, bet kartu su juo nukritusio raitelio koja susipainiojo balnakilpeje. Gulinčio kario vos nesutrypė kiti žirgai, tačiau, nusimovus batui, atsigavęs jis išsilaisvino ir nuskubejjo atgal pas saviškius. Gavęs nedidelị darbinị arklį, J. V. Počobutas Odlanickis nujojo ị tą pačią vietą ir kiek toliau rado gulintị savo žuvusi žirgą ${ }^{109}$.

1661 m. spalio 18-osios mūšyje su Rusijos kariuomenès vaivados Ivano Chovanskio pajejgomis, J. V. Počobuto Odlanickio žiniomis, puolančios rusų kariuomenès rikiuotę sudare penkios tvarkingos grupès ${ }^{110}$. Jas prie perkèlos pirmiausia turejo pasitikti lengvosios kavalerijos vèliavos. Vèliau nurodymą judèti gavo husarai. Kai intensyvi priešo artilerijos pabūklų ugnis paliete sunkiųjų kavaleristų eiles, šie patys paprašè nurodymo pulti. J. V. Počobuto Odlanickio žodžiais, gavę leidimą, husarai atakavo ir smogè priešui, tačiau ir patys patyrè nuostolių. Ši ataka buvo tik pirmoji. Lietuvos kariuomenès kavaleristas teigè, kad už perejos husarai susirèmè su priešu iki šešių kartų ( $i$ drugi, i trzeci, aż do szóstego razu potykaliśmy się, co raz za przeprawa). Ten pat ị kovą stojo ir kai kurios kitos vèliavos, praradusios daug žmonių ir žirgų ${ }^{111}$. Mūšyje dalyvavusio atsiminimų autoriaus manymu, lietuvių kavalerija patyrè daug nuostolių todèl, kad turejo kautis neparankioje vietoje (naszych siła nabito i nastrzelano, z tych przyczyn, że się we złym miejscu nam potykać przyszło). Rusijos kariuomenè užėmė mūšio lauką ir triumfavo: muškietų kulkos pasiekdavo lietuvių kariuomenès šancus ${ }^{112}$, o pabūklų sviediniai perlèkdavo per visą LDK stovyklą ${ }^{113}$.

Atsiminimuose husaras J. V. Počobutas Odlanickis džiaugèsi Karūnos dalinių remiamos ir pastiprinimą iš Lietuvos gavusios LDK kariuomenès atsakomuoju smūgiu I. Chovanskio armijai. Netoli Polocko lapkričio $4 \mathrm{~d}$.

\footnotetext{
109 J. Wł. Poczobut Odlanicki, Pamiętnik 1640-1684, oprac. A. Rachuba, s. 143.

110 Ten pat, s. 159.

111 Ten pat, s. 160.

112 Šancas (lenk. szaniec, rus. шанеu, vok. Schanze) - iš žemès suformuotas lauko fortifikacinis statinys - žemių pylimas ir fosa (griovys). Buvo naudojamas apsaugoti artilerijos pabūklams.
}

113 J. Wł. Poczobut Odlanicki, Pamiętnik 1640-1684, oprac. A. Rachuba, s. 162. 
ịvykusiame Kušlikų ${ }^{114}$ mūšyje jungtinès lietuvių ir lenkų pajègos atakavo caro kariuomenès užimtas pozicijas. Pasinaudojusios tiršta migla ir ịsibrovusios ị priešo stovyklą lietuvių ir lenkų kavalerijos vẻliavos, ịskaitant husarus, kurị laiką negalèjo atakuoti, mat šaudantys rusų pėstininkai buvo išsirikiavę už ispaniškųjų ožių ${ }^{115}$ ar panašių medinių kliūčių (stojąc przy tych kobylinach dawała ognia) ${ }^{116}$. Vèliau, atžygiavus ir su priešo kariais susišaudžius lietuvių ir lenkų pèstininkams, rusų daliniai gindamiesi atsitrauke iš stovyklos. Po kovos lauke, kai buvo išstumti ir iš naujos pozicijos, rusai atsitrauke į mišką. Husaro žodžiais, lietuvių ir lenkų kavalerija pralaužè priešo rikiuotę ir palaužè jo pasipriešinimą puldama kardais (rozerwali i w szable wzięli). Pergalę šventęs J. V. Počobutas Odlanickis nurodè didelị prie Kušlikų paimtų belaisvių skaičių ir gausų karo grobị ${ }^{117}$.

Karinèse kampanijose prieš Osmanų imperiją dalyvavusio husarų vèliavos draugo A. D. Skorobohato atsiminimuose dominuoja labai lakoniškas mūšių aprašymas. Chotyno mūšio išvakarèse, $1673 \mathrm{~m}$. lapkričio 10-osios ryte, atsiminimų autoriaus žiniomis, prie turkų ịtvirtinimų priartèjusios Lenkijos karalystės ir Lietuvos pajègos, tarp jų ir jo paties husarų vèliava, dieną ir naktị praleido rikiuotèje. Kai lapkričio $11 \mathrm{~d}$. ryte Karūnos didžiojo etmono Jono Sobieskio ir Lietuvos didžiojo etmono Mykolo Kazimiero Paco vadovaujamos kariuomenès pradèjo lemiamą apsuptų turkų įtvirtinimų puolimą ${ }^{118}$, lietuvių husaro žodžiais, jam su bendražygiais pavyko prasibrauti $\mathfrak{i}$ turkų pozicijas ir iškapoti daugybę

${ }^{114}$ Kušlikai (balt. Кушлiкi, lenk. Kuszliki) - kaimas dabartinès Baltarusijos šiaurèje, Polocko rajone.

${ }^{115}$ Ispaniškasis ožys, ispaniškai - „raitelis“ - lauko įtvirtinimų elementas, judejjimą stabdanti dirbtinè kliūtis, pagaminta iš storo tašo ir sukryžiuotų kuolų. Vietoj pastarųjų kartais būdavo pritvirtinami duriamieji ginklai.

${ }^{116}$ J. Wł. Poczobut Odlanicki, Pamiętnik 1640-1684, oprac. A. Rachuba, s. 164.

${ }^{117}$ J. Počobuto Odlanickio duomenimis, prie Kušlikų lietuviams ir lenkams atiteko penki ketiniai mažesni pabūklai, vienas didesnis, ko gero, ketvirtkartaunè (12-os svarų patranka), dvi mortyros, dešimt „odinių“ geležimi kaustytų pabūklų, 115 vèliavų, penki totoriški bunčiukai. Anot atsiminimų autoriaus, belaisviais tapo aštuoni pulkininkai, taip pat I. Chovanskio sūnus Andrejus, keliolika rotmistrų, apie du šimtus karininkų su reitarais. Ten pat, s. 164.

${ }^{118}$ Lapkričio 11 d. ryte turkų pozicijas apšaudè lenkų ir lietuvių artilerija. Vèliau turkų ịtvirtinimus juosusią fosą (prieš pylimą iškastą apsaugini griovị) įveike pėstininkai, kurie turèjo nukasti pylimą ir užpilti fosą jo žeme. Ivykdžius šią užduotị, turkų stovyklą turèjo atakuoti kavalerija. Kai tik atsirado galimybè, turkus atakavo husarų vèliavos. 
šturmu įveikto priešo karių ${ }^{119}$. Panašiai apibūdinamas ir $1683 \mathrm{~m}$. lapkričio 28 d. datuojamas mūšis prie Zinkivo ${ }^{120}$ su totoriais. Husaras ji aprašè vienu sakiniu: „Ordą sumušème <...> ir jasyrą ${ }^{121}$ kelių tūkstančių atèmėme." (Ordę znieśliśmy pod Zienkowem i jasyru odgromiliśmy na kilka tysięcy.) $)^{122}$

\section{PADARINIAI. NUOSTOLIAI}

$1655 \mathrm{~m}$. vasario $16 \mathrm{~d}$. Mogiliavo puolime dalyvavusios Lietuvos lauko etmono V. K. Gosevskio husaru vèliavos draugas Kristupas VorbekasLetovas prasitaré, kad iš miesto pro vartus prasiveržusios ir sunaikinimo išvengusios vèliavos kavaleristai pasièmé pozicijoje buvusị pabūklèli (działko), kablinį šautuvą (hakownica) ${ }^{123}$ ir pasitrauke prie savo kariuomenès ${ }^{124}$. Kautynèse V. K. Gosevskio husarų vèliavos nuostolius sudarè penki žuvę ir dvylika sužeistų karių, taip pat septyni kritę ir septyniolika sužeistų žirgų. Anot K. Vorbeko-Letovo, nemažai nuostolių patyrẻ ir kitos dvi vèliavos. Žuvo Stepono Franckevičiaus husarų vèliavos poručnikas $^{125}$. Mogiliavo $1655 \mathrm{~m}$. užimti nepavyko.

Aprašydamas mūšio prie Basios padarinius, J. V. Počobutas Odlanickis paminëjo karo grobiu tapusius dalykus. Jo žiniomis, lietuviai ir lenkai iš priešo atėmė 7 pabūklèlius, 15 vèliavų. Jis paminèjo ir Lietuvos

${ }^{119}$ A. D. Skorobohaty, Diariusz, oprac. T. Wasilewski, s. 123.

${ }^{120}$ Zinkivas (ukr. Зїньків, lenk. Zienków, Zinków) - kaimas dabartinès Ukrainos vakarinèje dalyje, Chmelnyckio srityje.

${ }^{121}$ Jasyras (lenk. jasyr, rus. яcbıps, ukr. яcup) - XV-XVIII a. vidurio istorinis terminas, kuriuo Vidurio ir Rytų Europos kraštuose buvo įvardijami turkų ir totorių žygiuose bei antpuoliuose į nelaisvę paimti žmonès. Belaisviai tapdavo vergais arba būdavo išperkami. Terminas ,jasyras“ paplito Lenkijoje ir Lietuvoje, įskaitant Ukrainos žemes, taip pat Maskvos valstybejje, kurių gyventojai dažniausiai ir patekdavo į nelaisvę. Jasyru buvo vadinamas ir pats buvimas turkų ar totorių nelaisveje.

${ }^{122}$ A. D. Skorobohaty, Diariusz, oprac. T. Wasilewski, s. 139.

${ }^{123}$ Kablinis šautuvas - sunkusis tvirtoves šautuvas su šūvio metu atatranką perimančiu kabliu.

${ }^{124}$ Kristupo Vorbeko-Letovo laiškas Motiejui Vorbekui-Letovui, M. Vorbek-Lettow, Skarbnica pamięci, s. 220-221.

${ }^{125}$ Ten pat, s. 221; R. Sikora, Niezwykłe bitwy i szarże husarii, s. 120. 
lauko etmono vèliavos praradimą, patvirtino, kad rusai atèmé artilerijos pabūklą (puskartaunę) ${ }^{126}$. Vardydamas saviškių nuostolius, atsiminimus palikęs husaras pirmiausia nurodè, kad žuvo rotmistras Mikalojus Šemeta (Mikołaj Szemiota). Surašè savo husarų vèliavos nuostolius: nukautas Jonas Losovskis (Jan Łosowski), pašautas Boguslavas Volanas (Bogusław Wolan), Kristupui Šumskiui (Krzysztof Szumski) pabūklo sviedinys nutraukè ranką, Uzdovskiui (Uzdowski) ịplèšè ranką, Chžonstovskiui (Chrząstowski) pike durta ị koją, Svencickiui (Święcicki) durta pike, Pakošui (Pakosz) perkirsta ranka. Nurodyti ir kitų Lietuvos kariuomenès husarų vèliavų nuostoliai ${ }^{127}$. Nors sparnuose išdèstytų M. K. Paco ir S. Čarneckio dalinių puolimas buvo sèkmingas, priešas sudavè stiprų smūgị kovos rikiuotès centre buvusiems P. Sapiegos divizijos pèstininkams. J. Počobutas Odlanickis konstatavo, kad „taip divizijai Pono Sapiegos nepasiseké" (tak się dywizyi Pana Sapiehy niepofortuniło), nurodé, kad žuvo 500 didžiojo etmono pèstininkų ${ }^{128}$.

J. V. Počobuto Odlanickio liudijimu, $1661 \mathrm{~m}$. spalio 18-osios kautynèse su Rusijos kariuomenès vaivados Ivano Chovanskio vadovaujamais daliniais didžiausius nuostolius patyrè V. K. Gosevskio husarų vèliava, kuri kelis kartus atakavo šaunamụjų ginklų ugnimi ją pasitinkantị priešą. Jo duomenimis, vèliava neteko 11 draugų, 9 palydos raitelių, prarado 35 žirgus. Atsiminimų autorius apgailestavo, kad mūšio lauke žuvo ir buvo sužeisti jo bendražygiai ${ }^{129}$. Tačiau čia pat husarų vèliavos draugas džiaugèsi savo pavaldinio sėkme. Jo žodžiais, „Dievo malone““ ir šalmas šyšakas ${ }^{130}$ apsaugojo palydos raitelio Bortkevičiaus (Bortkiewicz) veidą

\footnotetext{
126 Puskartaunè - 24 svarų patranka.

${ }^{127}$ J. Počobutas Odlanickis nurodè, kad Mykolo Kazimiero Radvilos vèliava neteko vèliavininko Čyžo (Czyż) ir dar kelių žmonių. Užsiminè ir apie Žemaitijos divizijos šarvininkų (kazokų) vèliavos karių Čiškevičiaus (Ciszkiewicz) ir Romaškevičiaus (Romaszkiewicz) žūtį. J. Wł. Poczobut Odlanicki, Pamiętnik 1640-1684, oprac. A. Rachuba, s. 145.

128 Ten pat, s. 144-145.

129 Ten pat, s. 160.

130 Šyšakas (lenk. szyszak, rus. щumaк, vengr. sisak, vok. zischägge) - atviras kūgio arba pusrutulio formos šalmas su skruostų, sprando ir nosies apsauga ir snapeliu. Kartais turẻdavo keterą (skiauterę). Skirtingos šio šalmo atmainos susiformavo vokiečių žemėse (vienas svarbiausių gamybos centrų - Niurnbergas), Vengrijoje, Lenkijos ir Lietuvos valstybeje, Rusijoje. Lenkijoje ir Lietuvoje XVI-XVIII a. šyšakus nešiojo daugiausia husarai. Paradiniai šyšakai buvo puošiami ornamentais, figūrinèmis kompozicijomis, auksuojami.
} 
pataikius muškietos kulkai. Iš atsiminimų teksto aiškèja, kad kulka pataikè į menka apsauga ịvardijamą nosalį ${ }^{131}$, todèl palydos raitelis atsipirko tik kraujuojančia nosimi ${ }^{132}$. Počobutas Odlanickis gailejosi kautynèse praradęs ir savo palydos žirgus: „vienas liko lauke, kitas, ant kurio pats sèdèjau, išnešęs mane iš ugnies, per šūvio iš lanko atstumą, būdamas tris kart peršautas, iškart krito ir nugaišo, trečias - taip pat sužalotas - liko tèvams bernardinams“"133.

\section{KARO VEIKSMŲ PABAIGA. SUGRİŽIMAS}

J. V. Počobutas Odlanickis aprašè sunkaus 1663-1664 m. žiemos žygio pabaigą ir (kovo 14 d.) išvykstančio valdovo Jono Kazimiero atsisveikinimą su išrikiuota kariuomene. Minima Lietuvos kanclerio Kristupo Zigmanto Paco kiekvienai husarų vèliavai perduota valdovo padèka už vargą ir darbą (za podjęte fatygi i prace) ir kalbinimas likti tarnyboje. Po kanclerio, judedamas nuo vienos vèliavos prie kitos, visai kariuomenei dar kartą dèkojo pats Jonas Kazimieras ${ }^{134}$. Baigiantis nesèkmingam žygiui, toliau i LDK besitraukiančios kavalerijos vèliavos girdèjo rytuose tebevykstančių karo veiksmų atgarsius. Nakvoti apsistoję husarai tolumoje galèjo girdèti su caro kariuomene susišaudančiu savo kariuomenès pèstininkų pabūklų gausmą ${ }^{135}$.

Grịžtantiems iš žygio kavaleristams trūko būtiniausių dalykų. Apsistojus kaime, ne visada pavykdavo surasti žirgams šieno. Žygiuojant atgal patirta įvairių materialinių nuostolių. Atsiminimuose J. V. Počobutas Odlanickis prasitaré, kad keliantis per vieną iš upių nuo balno lanko ị vandeni i ikrito ir nuskendo šyšakas (szyszak mój specjalny od półkirysia $z$

\footnotetext{
${ }^{131}$ Nosalis (angl. nasal, lenk. nosal) - atviro šalmo dalis, sauganti nosį, o kartais ir didesnę veido dalị.

${ }^{132}$ Tak właśnie temu memu pachołkowi cudownym kształtem zdarzyło się, iż go w pióro zapuszczone od szyszaka trafiono, że mu tylko nos kula muszkietowa rozkrwawiła i nic mu nie szkodziła, za tak mała zasłona. J. Wł. Poczobut Odlanicki, Pamiętnik 1640-1684, oprac. A. Rachuba, s. 160-162.

${ }^{133}$ Ten pat, s. 160.

134 Ten pat, s. 206-207.

135 Ten pat, s. 209.
} 
łęku spadłszy utonąt). Tačiau kovo pabaigoje galiausiai ịvykęs persikèlimas per Dnieprą reiškè, kad 1663-1664 m. žiemos žygyje dalyvavę LDK kariuomenès daliniai yra saugūs ir gali pailsèti apsistoję prie Mogiliavo. Atsiminimuose rašoma, kad $1664 \mathrm{~m}$. balandžio $9 \mathrm{~d}$. pasiekę ponios Izabelès Chodkevičienès (Izabella Chodkiewiczowa) valdas, husaras ir jo bendražygiai neturejo nè gabalo mèsos Velykoms, maitinosi po 10 grašiu už svarą pirktais lašiniais ${ }^{136}$.

$1664 \mathrm{~m}$. balandị ir gegužę praradęs savo palydos žirgus, J. V. Počobutas Odlanickis jojo ant paskutiniojo žirgo ir turèjo vieną darbinį arklị. Atsiminimuose jis džiūgavo gavęs galimybę atsigauti ir pataisyti materialinę padètị, kai buvo išrinktas deputatu vèliavai skirtoms lèšoms Plungèje ir Palangoje rinkti. Vasarą aplankęs Plungę, Žemaitijos Kalvariją, Palangą ir garsiąją Klaipédos mugę (byłem $z$ Połongi na jarmarku kłajpedzkim sławnym), rugsejji jis sudare su Palangos ir Plungès paseniūniu Uhliku (Uhlik) dešimties tūkstančių auksinų vertès sutartị dviem - jo malonybès karaliaus ir Mykolo Kazimiero Paco - husarų vèliavoms aprūpinti. Atsiminimuose jis paminèjo, kad spalị Tilžès mugèje, be mažmožių, nusipirko derešą (raudų ir baltų plaukų) žirgą, už jị sumokejęs 120 talerių (mokedamas taleriais ir raudonaisiais auksinais), kai taleris buvo vertas penkių auksinų. Lapkritị jis vèl kovėsi dvikovoje ir buvo sužeistas. Atsièmęs savo vèliavai skirtus pinigus, husaras išvyko iš Plungès link savo vèliavos. Savaitę praleidęs namie po pusantrų metų pertraukos ir paskutinị kartą pamatęs savo motiną, patrauke ị Ukmergę, kur turèjo atžygiuoti ir jo vèliava. Sulaukęs savo dalinio numatytoje vietoje, kavaleristas atsiskaitė už savo veiklą ir išdalijo kariams pinigus ${ }^{137}$.

Po motinos mirties $1665 \mathrm{~m}$. vasari J. V. Počobutas Odlanickis paveldèjo dalị tèvų palikimo, išrinktas deputatu $1666 \mathrm{~m}$. atstovavo savo kraštui Lietuvos tribunole ${ }^{138}$. Kariuomeneje tarnavo iki $1671 \mathrm{~m}$., kol buvo išformuota jo husarų vèliava. 12 metų toje pačioje vèliavoje ištarnavęs kavaleristas apie savo tarnybos kariuomeneje pabaigą rašè neslèpdamas nusivylimo. Už šešerius tarnybos kariuomenèje metus valdovo žadètų vaito pareigų, kaip ir bendražygiai, jis negavo. Jo žodžiais, už dvylikos metų tarnybą nebuvo atlyginta né vienu žemès valaku. Kariams teisètai

\footnotetext{
136 Ten pat, s. 210.

137 Ten pat, s. 212-213.

138 Ten pat, s. 214, 217.
} 
priklausančių apdovanojimų grobstymu husaras apkaltino LDK pulkininkus ir valdininkus (włóki nie dosłużyłem się, nie tylko wójtostwa, które teraz sami pułkownicy i urzędnicy Księstwa Litewskiego pochwycili przed towarzystwem bez wstydu $)^{139}$. Siekdamas gauti per daugelị metų užtarnautas algas, J. V. Počobutas Odlanickis ilgai turejjo dalyvauti iždo komisijose, atstovaudamas ir buvusiems bendražygiams ${ }^{140}$.

Ypatingai niūriomis spalvomis sugrịžimo iš paskutinès karinès kampanijos vaizdą nutape Lietuvos husarų vẻliavos karys Aleksandras Dionsas Skorobohatas. 1683 m. gruodị, žygio pabaigoje, jodamas jis susižeide ranką ir 1684 m. pasitiko sunkiai sirgdamas. Kavaleristo sveikatos būklè vasari pablogejo iki pat kaulo prasikirtus kairès kojos blauzdą. Po savaitès husaras neteko dvidešimt metų jam tarnavusio minèto tarno Žukausko $^{141}$. Palaidojęs bendražygi Trembovlios ${ }^{142}$ karmelitų bažnyčios rūsyje, sužeistas atsiminimų autorius pasuko link Lietuvos, palikęs savo palydą tarnauti vèliavoje. $1684 \mathrm{~m}$. kovo mėnesį, husarui jau būnant namuose, jam buvo iškilusi didelè gangrenos ir kojos praradimo grèsmè ${ }^{143}$. Šios nelaimès pavyko išvengti. Anot kavaleristo užrašų, vis dar rimtai nesveikuodamas, jis atliko husarų pareigą Krasniburo ${ }^{144}$ dominikonų bažnyčioje 1685 m. sausio 25 d., sulaužęs ietị pagerbiant mirusị poną Chreptavičių (Chreptowicz), o kovo 11 d. nuvyko i Varšuvos seimą. Kovo 19 d. soste esantị karalių husaras sveikino būdamas su ramentais (Króla JM. na tronie witałem na kulach) ${ }^{145}$.

Vèlesniais metais namuose kavaleristas buvo lankomas bendražygių, husarų vèliavos, kurioje tarnavo, poručniko ir draugų. $1688 \mathrm{~m}$. buvo pagerbtas - turejo galimybę būti šalia valdovo ir jì lydèti Gardino seimo

\footnotetext{
139 Ten pat, s. 263.

${ }^{140}$ R. Sikora, Fenomen husarii, s. 184; J. Wł. Poczobut Odlanicki, Pamiętnik 1640-1684, oprac. A. Rachuba, s. 79.

${ }^{141}$ A. D. Skorobohaty, Diariusz, oprac. T. Wasilewski, s. 140.

142 Trembovlia (ukr. Теребо́вля, lenk. Trembowlia) - miestas dabartinès Ukrainos vakarinèje dalyje, Ternopilio srityje.

143 A. D. Skorobohaty, Diariusz, oprac. T. Wasilewski, s. 141.

${ }^{144}$ Krasniburas (lenk. Krasnybór) - kaimas dabartinès Lenkijos šiaurès rytuose, Augustavo apskrityje.

145 A. D. Skorobohaty, Diariusz, oprac. T. Wasilewski, s. 142.
} 
$\operatorname{metu}^{146}$. Minëjome, kad po $1684 \mathrm{~m}$. žygyje patirtų sužeidimų husaras $\mathfrak{i}$ kariuomenę nebegrižo ir pats karo veiksmuose nebedalyvavo, tačiau toje pačioje vèliavoje toliau išlaikè palydą. Valdovo Jono Sobieskio Lietuvos husarų vèliavos sudetyje šis kovinis vienetas ir toliau dalyvavo žygiuose. Atsiminimų pabaigoje, rašydamas apie nesèkmingą $1691 \mathrm{~m}$. žygị, A. D. Skorobohatas pažymi praradęs visą husarų palydą su visa ekipuote ir žirgais. Karinę karjerą jis baigè jausdamas asmeninès nesèkmès kartèlị. Jo žodžiais, dèl Lenkijos ir Lietuvos valstybès sudètos aukos nebuvo atlygintos ${ }^{147}$.

Niūrios abiejų atsiminimus užrašiusių husarų mintys apie sunkios tarnybos pabaigą, nusivylimas karine ir politine vadovybe atskleidžia esmines kariuomenę silpninusias valstybès ydas. Jos turèjo didelę ịtaką tiek privilegijuotai, aristokratų pamėgtai kavalerijos formuotei, tiek visai kariuomenei.

\section{IŠVADOS}

Jono Počobuto Odlanickio ir Aleksandro Dionso Skorobohato pavyzdžiai liudija, kad husarų vèliavas sudarančių karių tarnyba prasidèdavo kitose kavalerijos formuotese, todèl husarais ịprastai tapdavo patyrę, mūšiuose jau dalyvavę žmonès. Husarų pasiruošimas karui asocijavosi su didžiulèmis išlaidomis, ypač apsirūpinant tinkamais žirgais. Karinių kampanijų eigą visapusiškai atspindinčiuose atsiminimuose daugiausia dẻmesio skirta neịprastais sunkumais išsiskiriantiems žygiams, pareikalavusiems skaudžių išgyvenimų ir netekčių.

XVII a. antrojoje puseje husarų išlaikomą elitinès kavalerijos statusą rodo ir jų reprezentacinès funkcijos. Lietuvos kariuomenès husarai tiesiogiai kontaktavo su valdovu, etmonais, buvo jų palydoje, mirus svarbiems asmenimis, pagerbdavo juos ginklu (sulaužydavo ietį). Husarų praktikuojamos dvikovos buvo daugiau nei büdas tarpusavio santykiams išsiaiškinti. Tai - svarbus kultūrinis bajoriškosios visuomenès reiškinys. Parodyta drąsa ir vikrumas turẻjo užtikrinti aukštą dvikovininkų ir jų

\footnotetext{
146 Ten pat, s. 144-147.

147 Ten pat, s. 151.
} 
palydų padètị dalinio hierarchijoje. Atsiminimų tekstai byloja, kad ịprastą stovyklos rutiną ir karių gyvenimą žygyje apsunkindavo ịvairūs incidentai (įskaitant dvikovas) ir ligos. Žygyje gurguolę turinčios husarų vèliavos judèdavo su visa kariuomene, o vykstant karinei operacijai ar rengiantis mūšiui, palikusios vežimus, jos igaudavo sparčiam judejimui reikiamo mobilumo ir manevringumo. Žygiuojant kariuomenei, husarų vèliavų kariai atlikdavo ir priešakinès sargybos užduotis.

Savo taktikos esmę husarai apibūdina ekspresyviai: ryžtingai atakavome, kontratakavome, padarème priešo rikiuoteje spragą, pralaužème priešo rikiuotę ir sukapojome jị kardais. Lietuvos kariuomenès tautinio autoramento sunkioji kavalerija buvo naudojama ir priešo įtvirtinimų šturmuose, todèl mūšiuose turèjo veikti lanksčiai, greitai reaguoti i pasikeitusią situaciją ir improvizuoti. Kaip matome iš visų LDK husaru tekstų, kovoje jie nestokodavo veržlumo ir išlaikydavo iniciatyvą, priešo kavaleristus Ł̣veikdavo kaudamiesi šaltaisiais ginklais, galèdavo sèkmingai atakuoti muškietininkus ir pikinierius, dalyvaudavo persekiojant palaužtą priešą. XVII a. pirmosios pusès reliacijos liudija, kad Lietuvos kariuomenès husarai buvo atsparūs priešo kavalerijos trumpavamzdžių ginklų (pirmiausia pistoletų) ugniai. Labai tikètina, kad šios savo savybès jie neprarado ir amžiaus antrojoje pusèje. Kliūtimi sẻkmingai atakuoti XVII a. antrosios pusės mūšiuose ịvardinti pėstininkų naudojami mobilūs lauko įtvirtinimai, ribota miesto gatvių erdvè.

Aprašydami mūšių padarinius, daugiausia dèmesio kariai skyrè savo ir priešo nuostoliams bei karo grobiui išvardinti. Nurodomos netektys žuvę ir sužeisti savo ir kitų Lietuvos kariuomenès kavalerijos vėliavų karininkai, draugai ir jų palydų raiteliai. Bendrais bruožais apibūdinami, paminimi ir pèstininkų dalinių praradimai. Prie nuostolių dažniausiai pateikiamas didelis žuvusių ir sužeistų žirgų skaičius. Nuosekliai rašydami apie prarastus žirgus, husarai fiksavo patiriamus materialinius nuostolius.

Atsiminimuose grịžimas iš žygio neretai aprašomas kaip sudètinga, pavojinga ir praradimų kupina karinès kampanijos dalis. Grižžmas i gimtinę asocijuodavosi ne tik su galimybe atgauti jègas ir kompensuoti patirtus nuostolius. Neišmokamos algos, nepakankama valstybės pagalba atlyginat sunkiosios kavalerijos kariams už kare patirtas netektis kèlè nusivylimą, ir tai aiškiai atsispindi husarų rašytuose tekstuose. Ši neigiama tendencija negalejo neprisidèti prie Lietuvos kariuomenès ir jos kavalerijos smogiamosios dalies silpimą skatinusių veiksnių. 
LDK husarų rašytinis palikimas yra ịvairiais požiūriais reikšminga šaltinių grupé, svarbi tiriant ne tik Lietuvos, bet ir kitų valstybių kariuomenių istoriją.

\section{ŠALTINIAI}

Diariusz prawdziwy expediciej Korony Polskiej y Wielkiego Xięstwa litewsk. Przeciw Osmanowi Cesarzowi Tureckiemu w roku 1621 Pod Chocimem $w$ Wołoszech fortunnie odprawioney, 1640.

Ekspedycyja inflantska 1621 roku, Białystok, 2007.

A. Gramont, Iš Jono Kazimiero žygio ị Maskvą istorijos (1663-1664), Lietuvos kariuomenè svetimšaliu akimis XVI-XVII a., Vilnius, 2009.

Korespondencja wojskowa hetmana Janusza Radziwiłla w latach 16461655, Część 1. Diariusz kancelaryjny 1649-1653, Warszawa, 2019.

Kristupo Vorbeko-Letovo laiškas Motiejui Vorbekui-Letovui iš: M. Vorbek-Lettow, Skarbnica pamięci, Wrocław-Warszawa-Kraków, 1968. Pamiętnik Jana Władysława Poczobuta Odlanickiego (1640-1684), Warszawa, 1877.

J. Wł. Poczobut Odlanicki, Pamiętnik 1640-1684, oprac. A. Rachuba, Warszawa, 1987.

B. Radziwiłł, Autobiografia, Warszawa, 1979.

A. D. Skorobohaty, Diariusz, oprac. T. Wasilewski, Warszawa, 2004.

А. Грамонь, Изг исторіи московскаго похода Яна Казимира (1663-1664 2. г.). Под ред. И. И. Лаппо, Юрьевь, 1929.

Г. Левассеръ де Бопланъ, Описаніе Украины отъ пределовъ Московіи до границъ Трансильваніи, составленное Гильомомъ Левассеръ де Бопланъ, В. Г. Ляскоронскій, Гильомъ Левассеръ де Боплань и его историко-геограбическіе труды относительно Южной Россіи. I. Описаніе Украины, II, Карты Украины, Кіевъ, 1901. 


\section{LITERATŪRA}

V. Airini, Pro Deo et Patria. Lietuvos Didžiosios Kunigaikštystès husarai 1500-1673. Abieju Tautu Respublikos husaru ginkluote Vytauto Didžiojo karo muziejaus rinkiniuose, Kaunas, 2013.

J. Janowski, Aleksander Hylary Połubiński. Działalność wojskowa w latach 1650-1665, Przeglad Historyczno-Wojskowy, Tom X, Warszawa, 1938.

K. Kossarzecki, Kampania roku 1660 na Litwie, Zabrze, 2005.

W. Łoziński, Życie polskie w dawnych wiekach, Kraków, 1969.

R. Sikora, Fenomen husarii, Warszawa, 2013.

R. Sikora, Niezwykłe bitwy i szarże husarii, Warszawa, 2012.

A. Tyla, Verkių mūšis (1658 10 21), Lituanistica, 2007, t. 69, Nr. 1.

A. Tyla, Lietuvos Didžiosios Kunigaikštystès iždas per dvidešimtmeti kara (1648-1667), Vilnius, 2010.

J. Wimmer, Wojsko polskie w drugiej połowie XVII w., Warszawa, 1965.

H. Wisner, Wojsko litewskie I połowy XVII wieku, cz. III, Studia $i$ materiały do historii wojskowości, Tom XXI, Wrocław-Warszawa-Kraków-Gdańsk, 1978.

А. В. Малов, Московские выборные полки солдатского строя в начальный период своей истории. 1656-1671 г2., Москва, 2006.

Iteikta $2020 \mathrm{~m}$. vasario $27 \mathrm{~d}$. 


\title{
WARS AND BATTLES OF THE SECOND HALF OF THE 17TH CENTURY IN THE TEXTS OF THE HUSSARS OF THE GRAND DUCHY OF LITHUANIA
}

\author{
Vidmantas AIRINI, \\ Klaipedda University, Institute of Baltic Region History and Archaeology
}

The 17th century was an era of extremely tough challenges to the Army of the Grand Duchy of Lithuania (GDL). At that time, it achieved significant victories but also suffered bitter defeats. The difficulties of financing the Army, conflicts among the ruling elite, frequent disagreements between the army leadership and the ruler's manor, war theatres frequently very far away from the borders of the duchy or wars with the enemies' armies in the occupied homeland territory were the actual circumstances the GDL Army fought in. The military correspondence, diaries and memoirs of soldiers were of particular importance for the investigation of the courses of military campaigns, battles, operations and preparation for military actions. These texts reveal the phenomena and events that, for various reasons, were silenced by official letters and personal notes of chiefs of defence and high-ranking officials. In the case of the GDL Army, the article singles out the written legacy of the hussar soldiers, i.e. the striking group of the Army.

The examples of Jonas Počobutas Odlanickis and Aleksandras Dionisas Skorobohatas, who served in the GDL Army at the second half of the 17th century, show that the service of the soldiers forming the hussar flags began in other cavalry formations; therefore, only the people having combat experience could become the hussars. The preparation of the heavy cavalry for war was associated with huge costs, especially in obtaining suitable horses.

At the second half of the 17th century, the status of the elite cavalry maintained by the hussars is very clearly revealed by their representative functions. The memoirs of the hussars testify that they were in direct contact with the ruler and hetmans, accompanied them and honoured the death of very important persons with weapons, i.e. by breaking a spear. The duels practiced by the hussars were an important cultural pheno- 
menon of a noble society. The demonstrated courage and dexterity ensured a high position for duellists in the hierarchy of a unit.

The texts also reveal that the daily routine at camps and life during marches were complicated by different incidents, including duels, and diseases. The hussar flags having the string of carts marched with the whole Army, whereas in a military operation or a battle they would leave the carts and become more mobile and manoeuvrable. In a march, the hussars performed the tasks of the forward petrol.

During the wars with Russia, Sweden and the Ottoman Empire in the second half of the 17th century, the hussars of the GDL Army described their tactics as follows: "We attacked and counterattacked resolutely, made a gap in the enemy's formation, broke through it and chopped it with swords". The Lithuanian heavy cavalry was used not only in an open field but also for attacking the enemy's fortifications. In the battles, the hussars had to operate flexibly, respond quickly to a changed situation and improvise. The hussars' texts witness that they did not lack swiftness, kept the initiative, defeated the enemy cavalry with cold weapons, could successfully attack musketeers and lancers and chased broken enemy. Identified as obstacles, the mobile field fortifications used by cavalry in battles were successfully attacked and the space of the city streets was confined.

In their descriptions of the consequences of the battles, the hussars focused on the losses and spoils. The killed and injured officers of own and other GDL cavalry, friends and their escort riders (privates) were considered as losses. The casualties of the infantry units were also described in general. The losses were usually given in high numbers of killed and injured horses. The cavalrymen consistently wrote about their lost horses and recorded the material losses incurred.

The return from a march was frequently characterized as a complex, dangerous and loss-making part of the military campaign and was associated not only with an opportunity to restore strength and recoup the losses. The memoirs reveal that the unpaid salaries and insufficient state compensation for the heavy cavalry losses in a war brought the hussars' disappointment. This negative tendency could not help but contribute to the factors influencing the attenuation of the striking power of the GDL Army and its cavalry.

The written legacy of the Lithuanian hussars who participated in the wars of the second half of the 17th century is a significant group of sources in different respects to the military history of Lithuania and other states. 